Article

\title{
Aux/IAA14 Regulates microRNA-Mediated Cold Stress Response in Arabidopsis Roots
}

\author{
Mohammad Aslam 1,2,3@ , Kenji Sugita 1, Yuan Qin 2,3® and Abidur Rahman 1,4,5,*(i) \\ 1 Department of Plant Bio Sciences, Faculty of Agriculture, Iwate University, Morioka 020-8550, Japan; \\ aslampmb1@gmail.com (M.A.); g0419022@iwate-u.ac.jp (K.S.) \\ 2 State Key Laboratory for Conservation and Utilization of Subtropical Agro-Bioresources, \\ Guangxi Key Lab of Sugarcane Biology, College of Agriculture, Guangxi University, Nanning 530004, \\ China; yuanqin@fafu.edu.cn \\ 3 Key Laboratory of Genetics, Breeding and Multiple Utilization of Crops, Ministry of Education, Fujian \\ Provincial Key Laboratory of Haixia Applied Plant Systems Biology, Center for Genomics and Biotechnology, \\ College of Agriculture, Fujian Agriculture and Forestry University, Fuzhou 350002, China \\ 4 United Graduate School of Agricultural Sciences, Iwate University, Morioka 020-8550, Japan \\ 5 Agri-Innovation Center, Faculty of Agriculture, Iwate University, Morioka 020-8550, Japan \\ * Correspondence: abidur@iwate-u.ac.jp
}

Received: 14 September 2020; Accepted: 4 November 2020; Published: 10 November 2020

\begin{abstract}
The phytohormone auxin and microRNA-mediated regulation of gene expressions are key regulators of plant growth and development at both optimal and under low-temperature stress conditions. However, the mechanistic link between microRNA and auxin in regulating plant cold stress response remains elusive. To better understand the role of microRNA ( $\mathrm{miR}$ ) in the crosstalk between auxin and cold stress responses, we took advantage of the mutants of Arabidopsis thaliana with altered response to auxin transport and signal. Screening of the mutants for root growth recovery after cold stress at $4{ }^{\circ} \mathrm{C}$ revealed that the auxin signaling mutant, solitary root 1 ( $\operatorname{sir} 1$; mutation in Aux/IAA14), shows a hypersensitive response to cold stress. Genome-wide expression analysis of miRs in the wild-type and slr 1 mutant roots using next-generation sequencing revealed 180 known and 71 novel cold-responsive microRNAs. Cold stress also increased the abundance of 26-31 nt small RNA population in $\operatorname{slr} 1$ compared with wild type. Comparative analysis of microRNA expression shows significant differential expression of 13 known and 7 novel miRs in $\operatorname{slr} 1$ at $4{ }^{\circ} \mathrm{C}$ compared with wild type. Target gene expression analysis of the members from one potential candidate miR, miR169, revealed the possible involvement of miR169/NF-YA module in the Aux/IAA14-mediated cold stress response. Taken together, these results indicate that SLR/IAA14, a transcriptional repressor of auxin signaling, plays a crucial role in integrating miRs in auxin and cold responses.
\end{abstract}

Keywords: cold stress; auxin; microRNA; $A u x / I A A$

\section{Introduction}

Cold stress is a serious threat to the sustainability of crop yield. In 2009, the chilling temperature alone resulted in crop damage equivalent to approximately 158 billion yen in Japan. Similarly, early and late frost results in damaging the vegetable and fruit production equivalent to 5-6 billion yen every year in Japan [1]. Cold stress also limits the geographical distribution of many important crop species [2]. In response to cold stress, plants show various phenotypic symptoms, including poor germination, stunted growth, yellowing of leaves (chlorosis), reduced leaf expansion, wilting of leaves, necrosis, and premature death [3]. Cold stress also severely affects the reproductive development of plants [4]. Exposure to stresses leads to changes in complex and interactive cellular and molecular processes 
required for physical adaptations and increased survival of the plants. Hence, a better understanding of the pathways that regulate plant growth during cold temperature stress is essential.

Hormonal regulation is one of the prime regulatory mechanisms involved in the survival of plants, which is a complex process comprising interactions of various hormones at transcriptional, translational, and cellular levels [5]. Among the hormones, auxin (indole-3-acetic acid, IAA) controls all aspects of plant growth and development, i.e., from embryogenesis to senescence [6]. Consistently, auxin has been shown to play an essential role in regulating plant growth and development under both high- and low-temperature stresses [1,7-11]. In Arabidopsis, cold stress seems to affect both auxin transport and signaling processes. Long-term cold stress results in coordinated down- and upregulations of Aux/IAA and ARF protein family, respectively [12], while short-term cold stress affects the polar transport of auxin through modulating GNOM-mediated intracellular cycling of PIN2, a detrimental process for the functionality of PIN proteins [9,13].

It was also demonstrated that cold stress alters the auxin homeostasis and considerably increases the auxin level in the root meristem, resulting in root growth inhibition. Restoring the auxin level through increased transport could restore the root growth even under cold stress $[9,13]$. Recently, the involvement of auxin maximum in the quiescent center (QC) has been shown to be an essential factor in preserving the root stem cells at a quiescent status under chilling stress [14]. The authors also demonstrated that this chilling stress-specific sacrifice-for-survival mechanism not only protects the stem cell niche from chilling stress but also improves the root's ability to withstand the accompanying environmental pressures and to recover when ambient temperatures rise to an optimal level [14]. In rice, $4{ }^{\circ} \mathrm{C}$ cold stress resulted in 1.2-1.6-fold increase in IAA level [15]. Differential expression of 3 auxin efflux carrier genes, 9 ARF genes, and $10 A u x / I A A$ genes was observed under cold stress [16]. The genome-wide analysis of the early auxin-responsive gene families in rice under cold stress revealed both up- and downregulation of several genes of the Gretchen Hagen 3 (GH3), AuxIAA, small auxin upregulated RNA (SAUR), and auxin response factor $(A R F)$ families [17]. OsGH3-2 overexpression-induced increase in cold tolerance was attributed to the combined effects of reduced free IAA content, alleviated oxidative damage, and decreased membrane permeability [18].

Additionally, it has also been shown that several known components of the cold signaling pathway are linked to auxin. For instance, SAP and MIZ1 domain-containing ligase1 (SIZ1), which is a central regulatory component of the cold response pathway and stabilizes inducer of CBF expression 1 (ICE1), is directly linked to auxin-mediated root architecture patterning $[19,20]$. Another downstream component of cold signaling pathway, nucleoporin 160 (AtNUP160), which plays a critical role in the nucleocytoplasmic transport of mRNAs under cold stress [21], has also been shown to play an essential role in auxin signaling [22]. Collectively, these results demonstrate the importance of auxin in regulating plants' cold response. However, what remains obscure are the molecular components that integrate auxin and cold stress response.

MicroRNAs (miRs) are small noncoding RNAs, usually consisting of 20-22 nucleotides for animals and 20-24 nucleotides for plants, that have emerged as ubiquitous post-transcriptional gene regulatory molecules [23]. miRs bind to complementary mRNA molecules and act as negative regulators of gene expression through endonucleolytic cleavage or translational repression of the cognate mRNA targets [24]. Lately, miR regulation of the stress response pathway has been established in several plant species [25-28]. Consistently, many cold-stress-responsive miRs have been identified in various plant species with variable results in different reports $[27,29,30]$. Upregulation of miRs, namely miR168, miR169, miR172, miR393, miR397, and miR395 during cold stress has been commonly observed in several plant species [31]. On the other hand, Lv et al. (2010) identified 18 cold-responsive miRs in rice, of which most were downregulated, indicating that the up- and/or downregulations of target genes controlled by miRs play an important role in a plant's adaptation to cold stress [32]. For instance, overexpression of miR408, which targets cuproproteins belonging to the phytocyanin family and laccase, results in cold tolerance $[33,34]$. Consistently, miR408 knockout lines show a hypersensitive response to cold stress [34]. Overexpression of miR397, which targets laccases and a casein kinase 
beta subunit 3, also results in increased freezing tolerance after cold acclimation [35]. Overexpression of miR394a and LCR have demonstrated the positive role of this miR-target pair in response to low-temperature stress [36]. In rice, miR319 overexpression lines show an increased survival rate under cold stress [37,38]. In trifoliate orange, overexpression of the precursor of ptr-miR396b results in enhanced cold tolerance [39]. Collectively, these results suggest that miRs are potential regulators of cold stress response pathways across the plant species.

Reports on miRs have also demonstrated their strong potentials in modulating auxin signal transduction, and several genes in auxin signaling have been reported as targets of miRs. For example, miR393 targets four closely related F-box genes, including the auxin receptor TIR1 [40,41]. miR393 also targets a basic helix-loop-helix transcription factor from Arabidopsis that is homologous to GBOF-1 from tulip and annotated as an auxin-inducible gene [42]. Interestingly, Liu et al. (2017) showed that the heterologous expression of rice miR393a results in enhanced cold tolerance in switchgrass (Panicum virgatum L.) [43]. Some auxin response factors ( $A R F s)$ have also been reported as targets of miRs [44,45]. ARF10, ARF16, and ARF17 are regulated by miR160 [46,47], while miR167 negatively regulates the expression of $A R F 2, A R F 3, A R F 4, A R F 6$, and ARF8 [48]. Few reports show that miR160 and the target $A R F s$ are conserved between dicots and monocots [49,50]. Liu et al. (2012) suggested that miR167 is essential for the appropriate expression of at least four OsARFs that contribute to the normal growth and development of rice [51]. Additionally, Lv et al. (2010) reported the involvement of miR167 during cold stress in rice, which had also been shown to be involved in regulating auxin signaling through modulating auxin response factors in several plant species [32,51-54]. Moreover, miR164 fine-tunes the auxin signals by targeting the NAC domain transcription factors [55]. Taken together, these findings suggest that miRs could be the potential link in integrating the auxin and cold stress responses.

In the present work, we tried to decipher the miRs that may regulate both auxin and cold stress responses by identifying auxin mutant that shows altered response to root growth after cold stress, followed by comparative analyses of genome-wide miRs in the wild type and a cold-stress-sensitive auxin mutant by deep sequencing. Our results revealed that $A u x / I A A 14$ mutant slr1 shows a hypersensitive response to cold-induced root growth inhibition. Comparative microRNA expression analysis displayed significant differential expression of 13 known and 7 novel miRs in slr 1 during cold stress compared with the wild-type. Interestingly, the majority of the differentially expressed miRs were downregulated in $\operatorname{sir} 1$ in comparison to the wild-type. The alteration of a significant number of miRs at $4{ }^{\circ} \mathrm{C}$ in the $\operatorname{sir} 1$ background suggests that SLR/IAA14 plays a crucial role in integrating cold and miR responses. Further, expression analysis of the target genes of one of the potential candidates, miR169, revealed that the miR169/NF-YA module may play an important role in integrating IAA14-mediated auxin signaling, $\mathrm{miR}$, and cold stress.

\section{Results}

\subsection{Auxin Signaling Mutant slr1 Is Susceptible to Low Temperature}

To better understand the role of auxin in cold stress response, we first focused on identifying the cold-responsive auxin mutants. The screening of the auxin mutants was performed based on the root growth recovery assay developed in our lab earlier [9]. Auxin signaling mutants slr1, tir1, axr1-3, and afb2-1 and auxin transport mutants aux1-7, eir1-1, pin3-3, and pin4-3 were subjected to cold stress screening [56-63]. The root elongation recovery was analyzed after 6 and $24 \mathrm{~h}$ of recovery (Figure 1) [9]. Consistent with previous results, we also found that cold stress inhibits root growth recovery by approximately 50\% in the wild type after $6 \mathrm{~h}$ (Figure 1A). Through root growth recovery screening, we could identify slr1, an Aux/IAA14 mutant as a potential candidate as slr1 showed slower root elongation recovery at both 6 and $24 \mathrm{~h}$ time points (Figure 1, Supplementary Figure S1). The other mutants did not show any significant difference compared with wild-type for root elongation recovery except auxin transport mutant pin4-3, which showed a slight but statistically significant slower root 
recovery response at $24 \mathrm{~h}$ (Figure 1). To further confirm whether slr1 response to cold stress persists for a longer time, we measured the root growth recovery till $24 \mathrm{~h}$ and found that $\operatorname{sir} 1$ showed slower root growth recovery at all time points tested (Figure 2A,B).
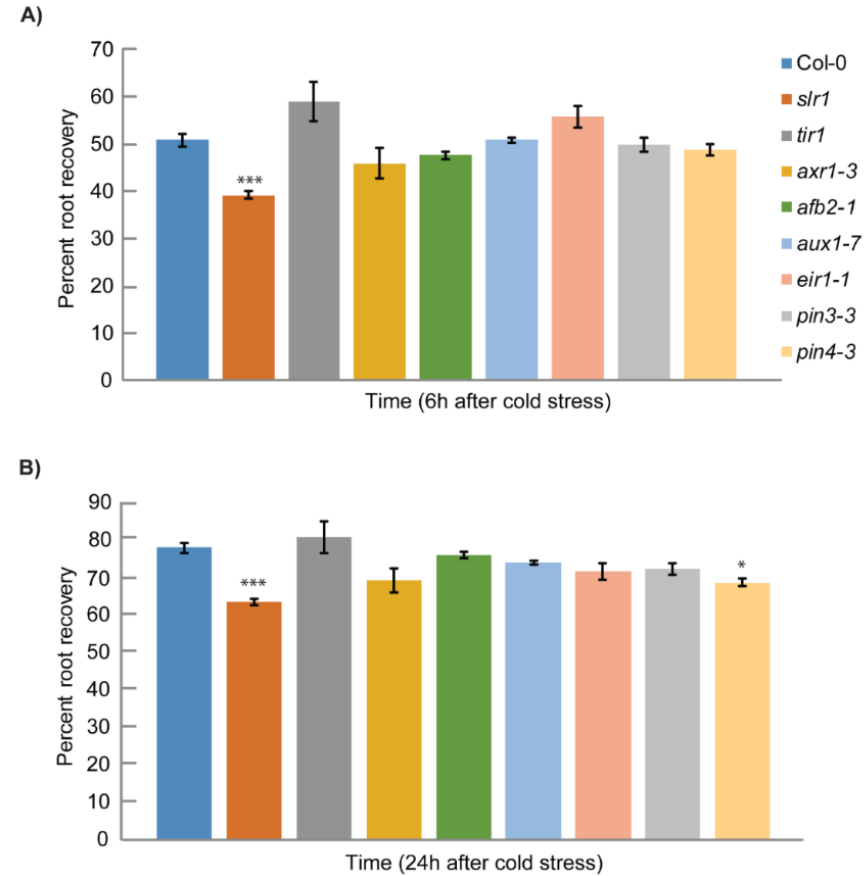

Figure 1. Screening of auxin mutants for root growth recovery response after cold stress: (A) percentage root growth recovery at $6 \mathrm{~h}$ after $12 \mathrm{~h}$ of cold stress; (B) percentage root growth recovery at $24 \mathrm{~h}$ after $12 \mathrm{~h}$ of cold stress. Root growth recovery was calculated against the root growth at $23^{\circ} \mathrm{C}$. Vertical bars represent mean \pm S.E. Data are from at least three independent experiments $(n=3$ or more) with $8-10$ seedlings per treatment. Asterisks denote the statistical significance between control and treatment as judged by the Student's $t$-test $\left({ }^{*} p<0.05\right.$ and $\left.{ }^{* * *} p<0.001\right)$.

A)

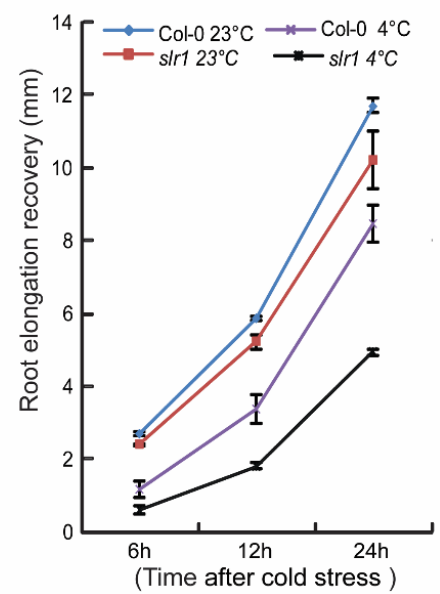

B)

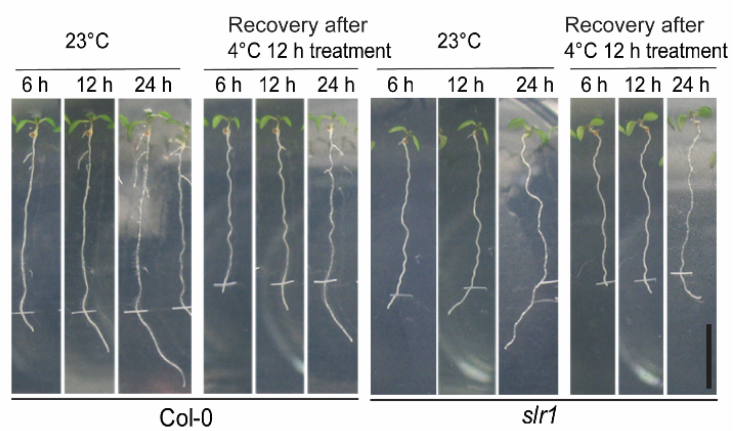

Figure 2. Auxin mutant $\operatorname{slr} 1$ shows hypersensitive response to cold stress: (A) Comparison of primary root elongation at optimal temperature $\left(23^{\circ} \mathrm{C}\right)$ and $12 \mathrm{~h}$ cold-stressed seedlings in wild type (Col- 0 ) and $\operatorname{slr} 1$. Note that slr1 shows slower root growth recovery compared with wild type at all time points we tested. Vertical bars represent mean \pm SE. Data are from at least three independent experiments ( $n=3$ or more) with $8-10$ seedlings per treatment. slr1 root growth recovery at $4{ }^{\circ} \mathrm{C}$ was statistically significant at all time points as judged by the Student's $t$-test. (B) Root phenotype of Col-0 and $\operatorname{sir} 1$ during $24 \mathrm{~h}$ recovery period after cold stress at $4{ }^{\circ} \mathrm{C}$ for $12 \mathrm{~h}$. Tick marks indicate the starting point of the recovery at $23^{\circ} \mathrm{C}$. Scale bar $=10 \mathrm{~mm}$. 


\subsection{High-Throughput Sequencing of Small RNA Libraries}

After identifying the auxin response mutant $\operatorname{slr} 1$ that shows hypersensitivity to cold-stress-induced root growth, we next focused on identifying the miRs that are responsive to auxin signaling-mediated cold stress response. For this, we performed a comparative RNAseq analysis between wild type (Col-0) and slr1 using Illumina high-throughput sequencing platform. After trimming the adaptor and low-quality reads, the sequence reads were generated. A total of 2,556,265 different tags were found from the trimmed reads, comprising 933,996 different tags from Col- 0 at $23^{\circ} \mathrm{C}, 441,338$ different tags from Col- 0 at $4{ }^{\circ} \mathrm{C}, 626,812$ different tags from slr 1 at $23^{\circ} \mathrm{C}$, and 554,119 different tags from slr 1 at $4{ }^{\circ} \mathrm{C}$ (Table 1). The nucleotide length distribution in all the libraries showed that most sequences ranged from 19 to $29 \mathrm{nt}$ in size. We found that 21-nt-long small RNAs were the most abundant in all four libraries, followed by $24 \mathrm{nt}$. The total abundance of the 21 and $24 \mathrm{nt}$ small RNA population types was $46.26 \%$ in Col- 0 at $23{ }^{\circ} \mathrm{C}, 56.44 \%$ in Col- 0 at $4{ }^{\circ} \mathrm{C}, 42.66 \%$ in $\operatorname{slr} 1$ at $23{ }^{\circ} \mathrm{C}$, and $30.43 \%$ in slr1 at $4{ }^{\circ} \mathrm{C}$ (Table 2). The significant change in small RNA abundance in the cold-stressed slr1 compared with the wild-type suggests the importance of auxin signaling in miR-modulated cold stress response. The populations of 26-31 nt small RNAs were drastically affected in slr1 background by cold stress as an increase in 26-31 nt was observed (Table 2). We also found a significant decrease in the $21 \mathrm{nt}$ small RNA population in $s l r 1$ under cold stress, while this population was increased in Col- 0 . These results further reinforce the idea that auxin signaling directly regulates miR expression (Figure 3, Table 2). We did not observe any significant changes in $24 \mathrm{nt}$ reads for treatments and genotypes (Table 2, Figure 3). The significant change in the major population of small RNAs in the slr1 mutant under cold stress confirms the involvement of auxin response in regulating miR functions linked to the cold stress response pathway, and it also provides a possible explanation for the hypersensitive response of $\operatorname{sir} 1$ to cold stress.

Table 1. Summary of small RNA libraries after deep sequencing.

\begin{tabular}{|c|c|c|c|c|c|c|}
\hline S1. No & Sample Name & Number of Reads & Average Length & $\begin{array}{c}\text { Number of Reads } \\
\text { after Trim }\end{array}$ & $\begin{array}{l}\text { Percentage } \\
\text { Trim }\end{array}$ & $\begin{array}{l}\text { Average Length } \\
\text { after Trim }\end{array}$ \\
\hline 1 & Col-0 $23{ }^{\circ} \mathrm{C} \_$Rep 1 & $47,318,921$ & 21.6 & $46,240,335$ & $97.72 \%$ & 21.6 \\
\hline 2 & Col- $023^{\circ} \mathrm{C} \_$Rep 2 & $38,919,856$ & 22.4 & $38,635,669$ & 99.27 & 22.4 \\
\hline 3 & Col-0 $4{ }^{\circ} \mathrm{C} \_\operatorname{Rep} 1$ & $30,230,648$ & 23.8 & $30,004,070$ & $99.25 \%$ & 23.8 \\
\hline 4 & Col-0 $4{ }^{\circ} \mathrm{C}_{-} \operatorname{Rep} 2$ & $23,124,483$ & 21.9 & $22,863,639$ & $98.87 \%$ & 21.9 \\
\hline 5 & $\operatorname{slr} 123{ }^{\circ} \mathrm{C} \_$Rep 1 & $22,247,497$ & 21.4 & $21,471,561$ & $95.51 \%$ & 21.4 \\
\hline 6 & slr1 $23^{\circ} \mathrm{C} \_$Rep2 & $43,063,180$ & 22.1 & $42,081,401$ & $97.72 \%$ & 22.1 \\
\hline 7 & $\operatorname{slr} 14^{\circ} \mathrm{C}_{-} \operatorname{Rep} 1$ & $25,807,408$ & 22.9 & $24,711,139$ & 95.75 & 22.4 \\
\hline 8 & $\operatorname{slr} 14^{\circ} \mathrm{C} \_$Rep2 & $43,591,146$ & 23.0 & $43,069,325$ & $98.8 \%$ & 23.0 \\
\hline
\end{tabular}

Table 2. Distribution of frequency percentage of nucleotide length.

\begin{tabular}{|c|c|c|c|c|c|c|c|c|c|}
\hline & \multirow{2}{*}{ Sample Name } & \multicolumn{8}{|c|}{ Frequency Percentage of nt Length } \\
\hline & & $21 \mathrm{nt}$ & $24 \mathrm{nt}$ & $26 \mathrm{nt}$ & $27 \mathrm{nt}$ & $28 \mathrm{nt}$ & $29 \mathrm{nt}$ & $30 \mathrm{nt}$ & $31 \mathrm{nt}$ \\
\hline 1 & Col- $023^{\circ} \mathrm{C}$ & 32.76 & 13.50 & 3.46 & 2.25 & 1.37 & 0.71 & 0.56 & 0.41 \\
\hline 2 & Col-0 $4{ }^{\circ} \mathrm{C}$ & 42.49 & 13.95 & 3.02 & 1.31 & 0.69 & 0.30 & 0.16 & 0.06 \\
\hline 3 & $\operatorname{slr} 123^{\circ} \mathrm{C}$ & 30.52 & 12.14 & 3.75 & 2.06 & 1.08 & 0.48 & 0.26 & 0.16 \\
\hline 4 & $\operatorname{slr} 14^{\circ} \mathrm{C}$ & 20.12 & 10.31 & 6.72 & 4.42 & 4.00 & 2.97 & 2.68 & 2.43 \\
\hline
\end{tabular}




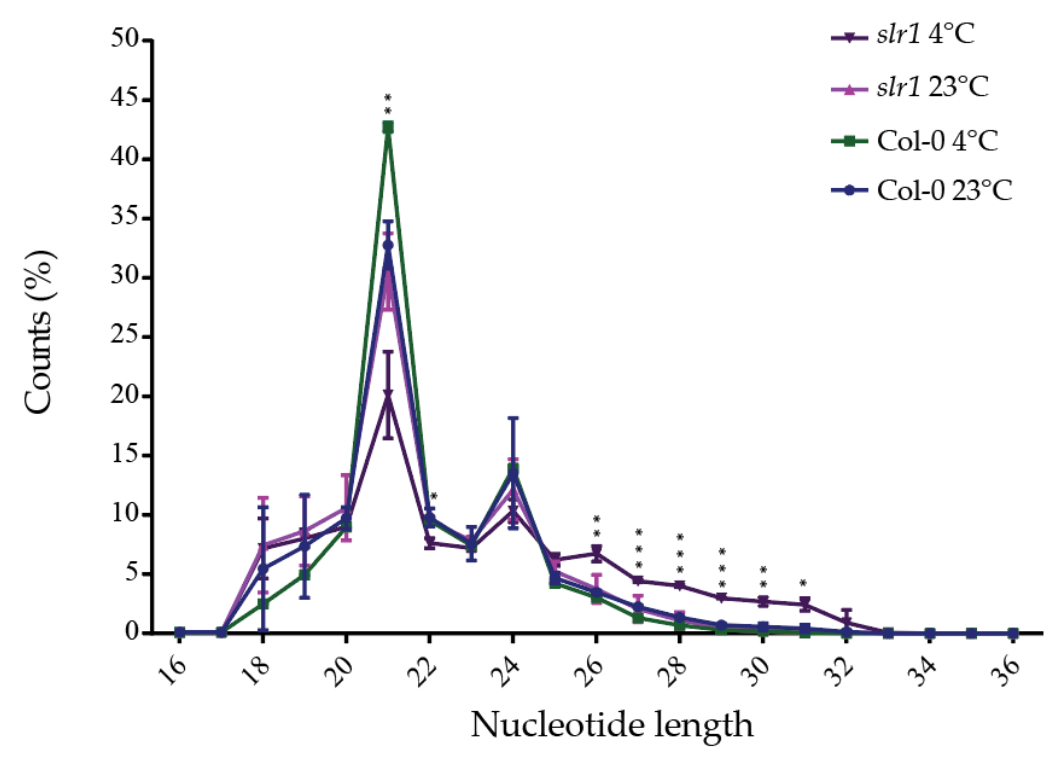

Figure 3. Nucleotide length distribution in wild type (Col-0) and slr1. Nucleotide length distribution of small RNA libraries. The results are obtained from two independent biological replicates. Vertical bars represent mean $\pm \mathrm{SD}$. Asterisks represent the statistical significance between the treatments as judged by the Student's $t$-test $\left({ }^{*} p<0.05,{ }^{* *} p<0.01\right.$, and $\left.{ }^{* *} p<0.001\right)$.

\subsection{Identification of Known and Novel miRs}

A total of 180 known miRs, representing 70 families, were identified in eight small RNA libraries made from root tissue (Figures 4 and 5, Supplementary Table S1). In all the eight libraries, the miR166 family was the most abundant, followed by miR165 and miR168 families. During low-temperature stress, we found differential expression patterns of miRs in the wild type and slr1 (Figure 4, Supplementary Table S1). The comparative analysis between cold-treated wild type and $s / r 1$ revealed that the expression of 13 miRs significantly changed in slr 1 during cold stress (Table 3 ). We also observed altered expression of $10 \mathrm{miRs}$ in slr 1 background between control and cold treatment (Table 3). Interestingly, the expression of all the miRs, except for one, was downregulated in slr1 mutant compared to wild type.

For the identification of novel miRs, mirDeep-P pipeline was used. A total of 71 sequences were predicted to be potentially novel miRs from unannotated small RNAs (Supplementary Tables S2 and S3, Supplementary Figure S2). The abundance of novel miRs was lower compared to conserved miRs, and their length varied from 19 to $30 \mathrm{nt}$. The comparative analysis of novel miRs between Col-0 and slr1 revealed that seven of them significantly changed in slr1 under cold stress (Table 4, Supplementary Figure S2). 


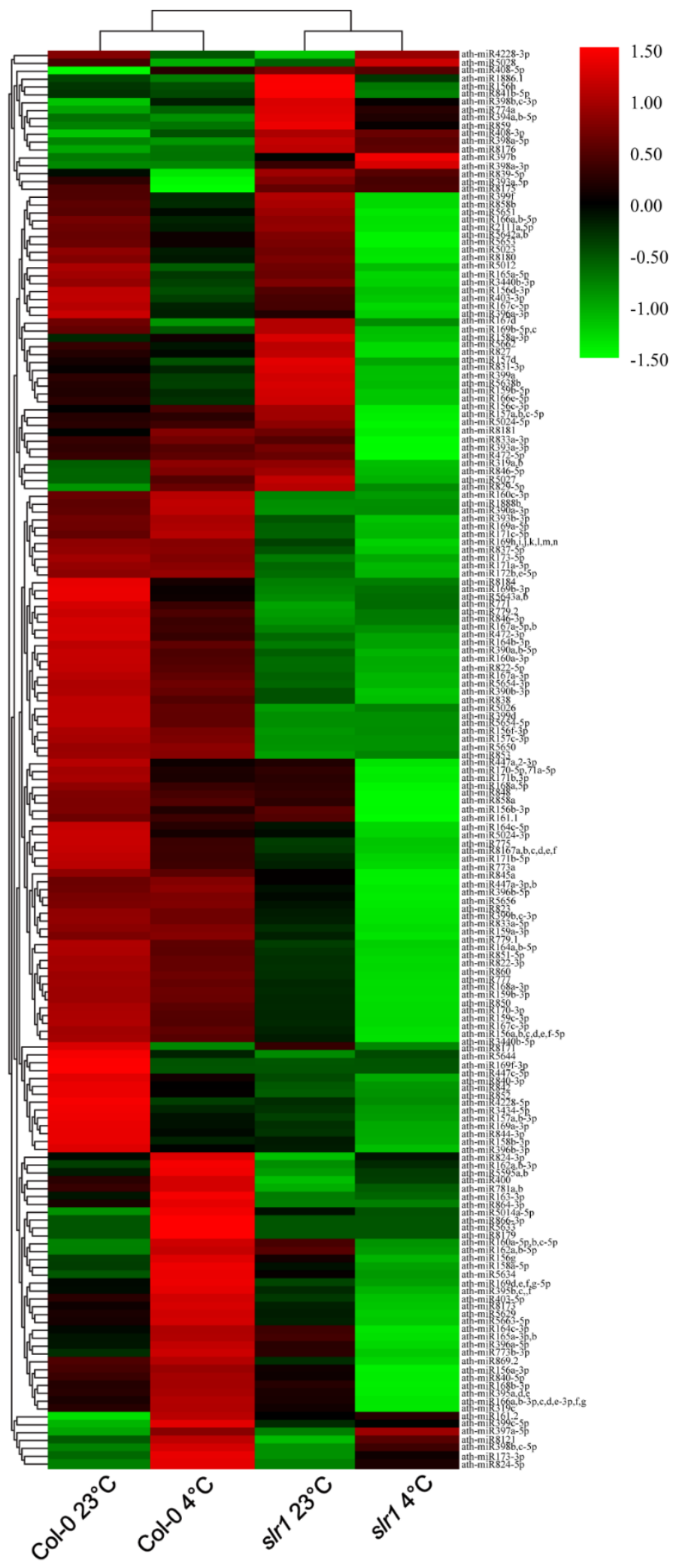

Figure 4. Known miR expression profiles in the root of wild type (Col-0) and slr1. The heat map shows the hierarchical cluster analysis of miRs regulated in the cold-stressed root of wild type and slr1. The color bars of the heatmap represent the gradient scale of normalized log2-TPM values for each miR. Red color indicates a high level of miR abundance, and green color indicates low abundance. The analysis was performed using two independent biological replicates. 
Table 3. List of known microRNAs (miRs) whose expression changed significantly during cold stress. Blue color represents the downregulation and red color represents upregulation in the expression in the mutant. Light green color represents Col- 0 and light pink color represents slr 1 genotypes respectively. The values in the temperature columns $\left(23^{\circ} \mathrm{C}\right.$ and $\left.4{ }^{\circ} \mathrm{C}\right)$ represent the normalized expression values. Data were obtained from two independent biological replicates. Statistical significance between the treatments and genotype was obtained using Student's $t$-test. ${ }^{a}$ Denotes miRs showing significantly altered expression between wild type and $\operatorname{sir} 1$ at $4{ }^{\circ} \mathrm{C}$.

\begin{tabular}{|c|c|c|c|c|c|c|c|c|}
\hline \multirow{3}{*}{ miR ID } & \multicolumn{3}{|c|}{ Col-0 } & \multicolumn{3}{|c|}{ slr1 } & \multirow{2}{*}{\multicolumn{2}{|c|}{$p$-Value Col-0 vs. slr }} \\
\hline & \multirow{2}{*}{$23^{\circ} \mathrm{C}$} & \multirow{2}{*}{$4^{\circ} \mathrm{C}$} & \multirow{2}{*}{$\begin{array}{c}p \text {-Value } \\
23{ }^{\circ} \mathrm{C} \text { vs. } 4{ }^{\circ} \mathrm{C}\end{array}$} & \multirow{2}{*}{$23^{\circ} \mathrm{C}$} & \multirow{2}{*}{$4{ }^{\circ} \mathrm{C}$} & \multirow{2}{*}{$\begin{array}{c}p \text {-Value } \\
23{ }^{\circ} \mathrm{C} \text { vs. } 4{ }^{\circ} \mathrm{C}\end{array}$} & & \\
\hline & & & & & & & $23^{\circ} \mathrm{C}$ & $4{ }^{\circ} \mathrm{C}$ \\
\hline miR156a,b,c,d,e,f, & 114.53 & 100.9 & 0.809 & 78.61 & 54.51 & 0.654 & 0.648 & $0.002^{a}$ \\
\hline miR164b-3p & 22.5 & 13.47 & 0.611 & 3.64 & 2.79 & 0.447 & 0.338 & $0.006^{\mathrm{a}}$ \\
\hline miR169a-5p & 26.49 & 30.81 & 0.613 & 15.9 & 12.7 & 0.587 & 0.296 & $0.059^{a}$ \\
\hline miR170,miR171a-5p & 4.7 & 2.96 & 0.638 & 3.17 & 0.92 & 0.051 & 0.652 & 0.27 \\
\hline miR390a,b-5p & 1385 & 812.14 & 0.423 & 383.72 & 263.68 & 0.341 & 0.223 & $0.029^{a}$ \\
\hline miR390b-3p & 65.18 & 49.73 & 0.583 & 25.47 & 16.48 & 0.254 & 0.237 & $0.029^{a}$ \\
\hline miR396b-3p & 6.34 & 2.97 & 0.389 & 2.72 & 1.38 & 0.009 & 0.36 & $0.018^{a}$ \\
\hline miR398a-5p & 0.56 & 0.48 & 0.854 & 2.87 & 1.88 & 0.603 & 0.297 & $0.013^{a}$ \\
\hline miR399a & 4 & 3.15 & 0.165 & 5.65 & 2.31 & 0.049 & 0.148 & 0.224 \\
\hline $\operatorname{miR} 399 b, c-3 p$ & 25.8 & 23.93 & 0.845 & 17.41 & 10.81 & 0.027 & 0.413 & $0.029^{a}$ \\
\hline $\operatorname{miR} 408-5 p$ & 14.55 & 33.15 & 0.249 & 42.01 & 37.83 & 0.684 & 0.034 & 0.764 \\
\hline miR447a-3p,miR447 & 21.39 & 23 & 0.864 & 15.29 & 6.72 & 0.036 & 0.43 & 0.105 \\
\hline miR472-3p & 379.33 & 154.02 & 0.539 & 63.04 & 45.1 & 0.241 & 0.41 & $0.04^{\mathrm{a}}$ \\
\hline $\operatorname{miR} 5642 a, b$ & 77.64 & 62.74 & 0.059 & 82.11 & 34 & 0.239 & 0.891 & $0.028^{a}$ \\
\hline miR5656 & 1.31 & 1.33 & 0.982 & 0.81 & 0.18 & 0.044 & 0.235 & 0.257 \\
\hline miR773a & 419.47 & 248.54 & 0.605 & 167.81 & 77.04 & 0.032 & 0.465 & $0.019^{a}$ \\
\hline miR774a & 0.21 & 0.3 & 0.496 & 0.85 & 0.51 & 0.327 & 0.028 & 0.495 \\
\hline $\operatorname{miR775}$ & 26.11 & 15.41 & 0.621 & 9.78 & 5.68 & 0.266 & 0.472 & $0.04^{\mathrm{a}}$ \\
\hline miR8180 & 0.85 & 0.5 & 0.257 & 0.83 & 0.13 & 0.048 & 0.914 & 0.257 \\
\hline miR8181 & 1.49 & 2.08 & 0.567 & 1.98 & 0.73 & 0.018 & 0.25 & 0.243 \\
\hline $\mathrm{miR} 824-3 p$ & 177.08 & 365.65 & 0.267 & 99.59 & 171 & 0.037 & 0.484 & 0.149 \\
\hline miR850 & 8.16 & 6.72 & 0.685 & 3.71 & 1.52 & 0.103 & 0.017 & 0.238 \\
\hline miR852 & 3.7 & 1.72 & 0.468 & 1.15 & 0.9 & 0.384 & 0.372 & $0.058^{a}$ \\
\hline
\end{tabular}

A)

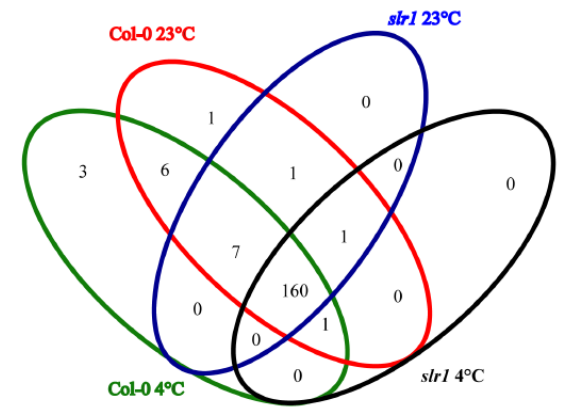

B)

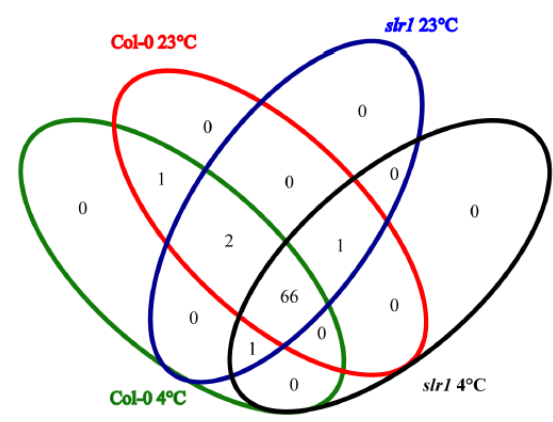

Figure 5. Venn diagram analysis showing the overlap of miRs among four libraries. (A) Known miRs identified in auxin-mediated cold stress response. (B) Novel miRs identified in auxin-mediated cold stress response. 
Table 4. List of predicted miRs whose expression changed significantly during cold stress. Blue color represents the downregulation and red color represents upregulation in the expression in the mutant. Light green color represents Col-0 and light pink color represents slr 1 genotypes respectively. Data were obtained from two independent biological replicates. The values in the temperature columns $\left(23{ }^{\circ} \mathrm{C}\right.$ and $4{ }^{\circ} \mathrm{C}$ ) represent the normalized expression values. Statistical significance between the treatments and genotype was obtained using Student's $t$-test. ${ }^{a}$ Denotes miRs showing significantly altered expression between wild type and $\operatorname{slr} 1$ at $4{ }^{\circ} \mathrm{C}$.

\begin{tabular}{|c|c|c|c|c|c|c|c|c|}
\hline \multirow{3}{*}{ miR ID } & \multicolumn{3}{|c|}{ Col-0 } & \multicolumn{3}{|c|}{ slr1 } & \multirow{2}{*}{\multicolumn{2}{|c|}{$p$-Value Col-0 vs. slr1 }} \\
\hline & \multirow{2}{*}{$23^{\circ} \mathrm{C}$} & \multirow{2}{*}{$4^{\circ} \mathrm{C}$} & \multirow{2}{*}{$\begin{array}{c}p \text {-Value } \\
23{ }^{\circ} \mathrm{C} \text { vs. } 4{ }^{\circ} \mathrm{C}\end{array}$} & \multirow{2}{*}{$23^{\circ} \mathrm{C}$} & \multirow{2}{*}{$4{ }^{\circ} \mathrm{C}$} & \multirow{2}{*}{$\begin{array}{c}p \text {-Value } \\
2{ }^{\circ} \mathrm{C} \text { vs. } 4{ }^{\circ} \mathrm{C}\end{array}$} & & \\
\hline & & & & & & & $23^{\circ} \mathrm{C}$ & $4^{\circ} \mathrm{C}$ \\
\hline Pred_7 & 30.68 & 16.18 & 0.521 & 36.20 & 69.86 & 0.033 & 0.84 & $0.015^{a}$ \\
\hline Pred_9 & 27.75 & 21.95 & 0.483 & 17.38 & 12.98 & 0.274 & 0.294 & $0.007^{\mathrm{a}}$ \\
\hline Pred_11 & 10.06 & 6.75 & 0.637 & 15.59 & 21.14 & 0.289 & 0.506 & $0.018^{\mathrm{a}}$ \\
\hline Pred_19 & 10.24 & 6.64 & 0.271 & 6.71 & 4.67 & 0.434 & 0.383 & $0.0031^{a}$ \\
\hline Pred_25 & 3.38 & 1.59 & 0.185 & 2.15 & 0.98 & 0.002 & 0.305 & $0.011^{\mathrm{a}}$ \\
\hline Pred_26 & 6.32 & 5.14 & 0.647 & 2.90 & 1.74 & 0.503 & 0.304 & $0.056^{\mathrm{a}}$ \\
\hline Pred_27 & 4.01 & 4.49 & 0.774 & 3.03 & 2.17 & 0.302 & 0.040 & 0.280 \\
\hline Pred_35 & 2.80 & 1.26 & 0.099 & 1.49 & 0.48 & 0.071 & 0.029 & 0.294 \\
\hline Pred_36 & 2.19 & 2.92 & 0.755 & 3.08 & 1.81 & 0.039 & 0.107 & 0.638 \\
\hline Pred_37 & 2.30 & 1.41 & 0.007 & 3.57 & 2.38 & 0.247 & 0.010 & 0.313 \\
\hline Pred_44 & 1.47 & 0.78 & 0.015 & 1.01 & 0.43 & 0.466 & 0.551 & 0.076 \\
\hline Pred_47 & 0.99 & 0.66 & 0.387 & 0.30 & 0.33 & 0.827 & 0.012 & 0.411 \\
\hline Pred_53 & 0.64 & 1.03 & 0.743 & 1.20 & 1.27 & 0.941 & 0.058 & 0.868 \\
\hline Pred_60 & 0.31 & 0.33 & 0.835 & 0 & 0 & 0 & 0.000 & $0.040^{a}$ \\
\hline Pred_62 & 0.22 & 0.14 & 0.060 & 0.001 & 0.147 & 0.116 & 0.001 & 0.983 \\
\hline Pred_65 & 0.26 & 0.28 & 0.966 & 1.21 & 0.647 & 0.475 & 0.015 & 0.658 \\
\hline
\end{tabular}

\subsection{Validation of miR Expression Patterns}

The consistency in miR expression identified by deep sequencing was validated using quantitative real-time PCR. We selected 13 differentially expressed miRs that were regulated in response to cold in the root. The validation was performed using 10 known miRs (miR156, miR164b-3p, miR169a-5p, miR171-5p, miR390-5p, miR5642a, miR408-5p, miR398a-5p, miR472-3p, and miR774a-5p) and 3 novel miRs (miR_Pred7, miR_Pred27, and miR_Pred37). With the exceptions of miR472 and miR_Pred7, qRT-PCR validation results of the expression of all other miRs showed a trend similar to that of the deep sequencing data, confirming that the observed differences of miR expression using three biological replicates are fairly consistent and reproducible (Figure 6).

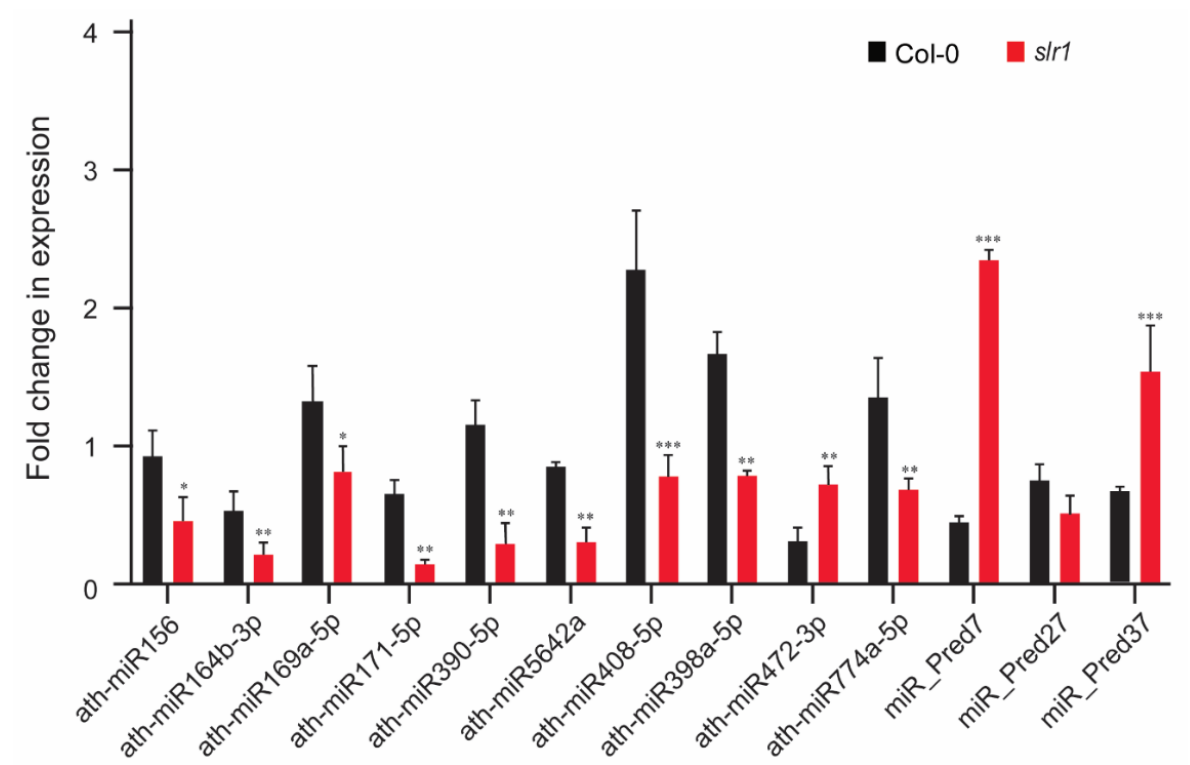

Figure 6. Validation of miR expression in response to cold stress. RT-qPCR validation of selected miRs from cold stress NGS library. Vertical bars represent the mean \pm SE of three biological replicates. Asterisks represent the statistical significance between control and treatment as judged by the Student's t-test $\left(^{*} p<0.05,{ }^{* *} p<0.01\right.$, and $\left.{ }^{* * *} p<0.001\right)$. 


\section{5. miR Target Prediction}

The degree of sequence complementarity between miR and its binding site within the target determines the mode of action of miR. High sequence complementarity results in cleavage of targets $[47,64,65]$, while low sequence complementarity results in translational inhibition [66,67]. Several online resources, such as psRNATarget, use the same strategy to identify the plant miR targets. We carried out target prediction to understand the function of identified miRs by using psRNATarget server with preset values. The predicted targets for these miRs were from different classes of proteins associated with development, transport, auxin regulation, signaling, and stress response (Figure 7, Supplementary Tables S1 and S2). For instance, cold stress response and signaling related proteins were targeted by miRs such as miR396b-3p, which targets MYB-like transcription factors, and miR156, which targets SQUAMOSA promoter-binding protein-like (SPL) transcription factor (Table 5). miRs like $\mathrm{miR} 390 \mathrm{a} / \mathrm{b}-5 \mathrm{p}$ target the TASI-ARF, which is involved in auxin signaling. The possible roles of the target proteins in integrating auxin and cold stress responses are discussed in detail in the discussion section. In general, we predict that the regulation of essential proteins contributing to cold stress tolerance in slr1 is possibly linked to the cold-susceptible phenotype of the mutant.

A)

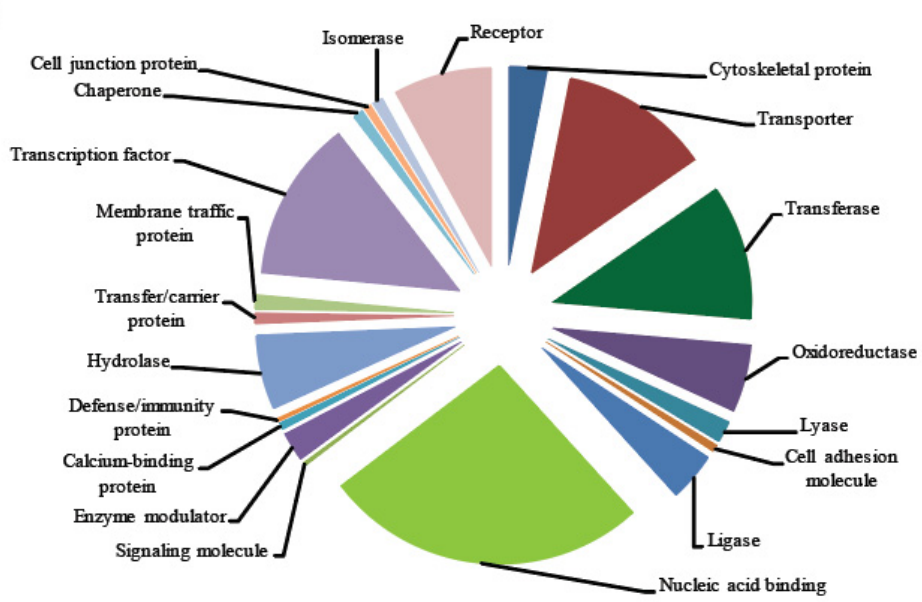

B)

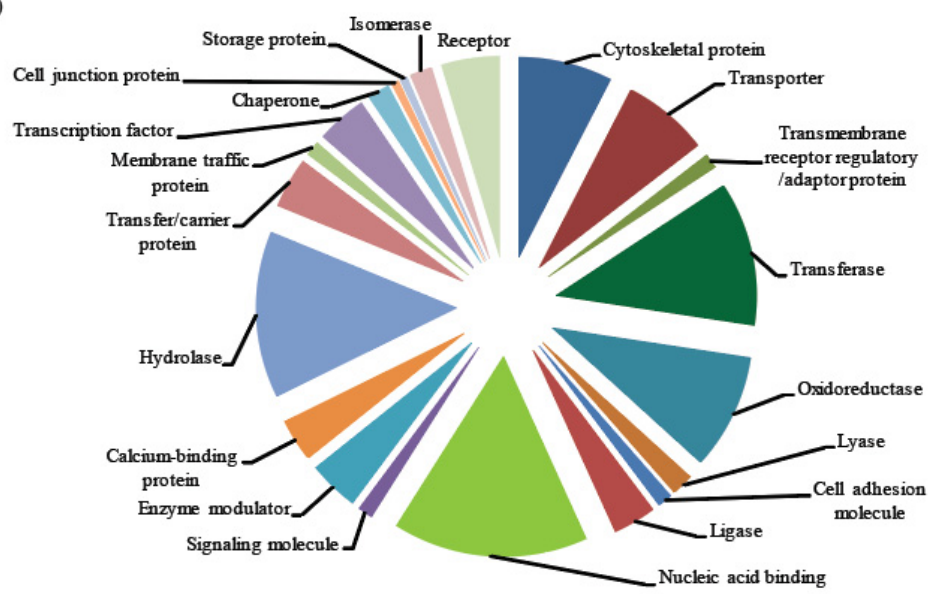

Figure 7. Pie charts showing the classes of proteins targeted by identified miRs: (A) protein classes targeted by known miRs; (B) protein classes targeted by novel miRs. 
Table 5. Predicted miR target list.

\begin{tabular}{|c|c|}
\hline miR ID & Target Locus \\
\hline $\operatorname{miR} 156 a, b, c, d, e, f$, & $\begin{array}{l}\text { SQUAMOSA promoter-binding protein-like } 15 \text { (AT3G57920), SQUAMOSA promoter-like 11 } \\
\text { (AT1G27360), SPL13B (AT5G50670), SPL9 (AT2G42200), SPL2 (AT5G43270), SPL10 (AT1G27370), } \\
\text { SPL13A (AT5G50570), SPL10 (AT1G27370), SBP domain transcription factor (AT1G69170), SPL3 } \\
\text { (AT2G33810), protein kinase superfamily protein (AT3G28690), SPL4 (AT1G53160), SPL5 (AT3G15270), } \\
\text { transposable element gene (AT1G16660), cysteine/histidine-rich C1 domain family protein (AT2G21840) }\end{array}$ \\
\hline miR164b-3p & PPR repeat protein (AT5G14770) \\
\hline miR169a-5p & Nuclear factor Y, subunit A8 (AT1G17590, AT1G54160) \\
\hline miR170, miR171a-5p & $\begin{array}{l}\text { Transposable element gene (AT2G06790, AT3G30393, AT1G36470, AT1G50860, AT3G29732, AT2G12305), } \\
\text { MATE efflux family protein (AT1G15180), F-box family protein (AT5G3946) }\end{array}$ \\
\hline $\operatorname{miR} 390 a, b-5 p$ & TASIR-ARF (AT5G57735), transmembrane kinase-like 1 (AT3G24660) \\
\hline miR390b-3p & $\begin{array}{l}\text { Vacuolar protein sorting } 11 \text { (AT2G05170), RNA-binding (RRM/RBD/RNP motifs) family protein } \\
\text { (AT3G07810), transposable element gene (AT2G41570, AT1G35990), clathrin heavy chain (AT3G11130) }\end{array}$ \\
\hline miR396b-3p & MYB76 (AT5G07700), ATBTAF1 (AT3G54280), RNA helicase family protein (AT1G58060) \\
\hline miR398a-5p & $\begin{array}{l}\text { SETH2, UDP-glycosyltransferase superfamily protein (AT3G45100); alpha/beta-hydrolases superfamily } \\
\text { protein (AT3G48080); ARM repeat superfamily protein (AT5G06120) }\end{array}$ \\
\hline miR399a & $\begin{array}{l}\text { PHO2/UBC24 (AT2G33770), CYP705A30 (AT3G20940), terpenoid cyclases family protein (AT1G78500), } \\
\text { sodium bile acid symporter family (AT2G26900), transposable element gene (AT3G43867), nucleic } \\
\text { acid-binding (AT1G27750) }\end{array}$ \\
\hline miR399b,c-3p & PHO2 (AT2G33770), wall-associated kinase 2 (AT1G21270) \\
\hline $\operatorname{miR} 408-5 p$ & $\begin{array}{l}\text { Oxidoreductase, 2OG-Fe(II) oxygenase (AT4G02940, AT4G25310), nucleotide/sugar transporter family } \\
\text { (AT4G03950), glutathione S-transferase TAU 25 (AT1G17180), leucine-rich repeat protein kinase family } \\
\text { protein (AT1G04210), unknown protein (AT4G37030), pseudogene (AT2G31860), calmodulin-binding } \\
\text { protein-related (AT5G10660), early-responsive to dehydration stress protein (AT4G35870) }\end{array}$ \\
\hline miR447a-3p, miR447b & $\begin{array}{l}\text { P-loop containing nucleoside triphosphate (AT5G60760), FAD-dependent oxidoreductase family protein } \\
\text { (AT2G22650), IncRNA (AT5G05905) }\end{array}$ \\
\hline $\operatorname{miR} 472-3 p$ & $\begin{array}{l}\text { Disease resistance protein (CC-NBS-LRR class) family (AT5G43740, AT1G12290, AT1G15890); RPS5, } \\
\text { disease resistance protein (CC-NBS-LRR class) family (AT1G12220) }\end{array}$ \\
\hline $\operatorname{miR} 5642 a, b$ & $\begin{array}{l}\text { Tryptophan synthase beta-subunit } 1 \text { (AT5G54810); VHA-E3, vacuolar H+-ATPase subunit E isoform } 3 \\
\text { (AT1G64200) }\end{array}$ \\
\hline miR5656 & $\begin{array}{l}\text { Mitochondrial editing factor } 9 \text { (AT1G62260), zinc finger (C3HC4-type RING finger) family protein } \\
\text { (AT5G60710), transposable element gene (AT3G29787) }\end{array}$ \\
\hline miR773a & $\begin{array}{l}\text { Remorin family protein (AT3G57540), root FNR } 1 \text { (AT4G05390), Acyl-CoA N-acyltransferase with } \\
\text { RING/FYVE/PHD-type zinc finger protein (AT4G14920), transposable element gene (transposable } \\
\text { element gene), RAD3-like DNA-binding helicase protein (AT1G79950), oleosin3 (AT5G51210) }\end{array}$ \\
\hline miR774a & $\begin{array}{l}\text { F-box and associated interaction domains-containing protein (AT3G17490), F-box family protein } \\
\text { (AT3G19890), transposable element gene (AT1G34405, AT2G01024, AT4G16910, AT3G42996, } \\
\text { AT2G07660) }\end{array}$ \\
\hline $\operatorname{miR775}$ & $\begin{array}{l}\text { Dicer-like } 1 \text { (AT1G01040), galactosyltransferase family protein (AT1G53290), galactosyltransferase } \\
\text { family protein (AT1G53290) }\end{array}$ \\
\hline miR8180 & $\begin{array}{l}\text { Alpha/beta-hydrolases superfamily protein (AT3G55190), plastid division2 (AT2G16070), } \\
\text { ATP-dependent helicase family protein (AT2G28240), IncRNA (AT3G08825), fatty acid reductase } 1 \\
\text { (AT5G22500), }\end{array}$ \\
\hline miR8181 & $\begin{array}{l}\text { Ovate family protein (AT2G36026), cysteine/histidine-rich C1 domain family protein (AT1G55430), LOB } \\
\text { domain-containing protein } 39 \text { (AT4G37540), transposable element gene (AT3G30713) }\end{array}$ \\
\hline miR824-3p & $\begin{array}{l}\text { Concanavalin A-like lectin protein kinase family protein (AT3G08870), pentatricopeptide repeat } \\
\text { (PPR)-containing protein (AT5G27300) }\end{array}$ \\
\hline miR850 & $\begin{array}{l}\text { Chloroplast RNA binding (AT1G09340), threonyl-tRNA synthetase (AT2G04842), lncRNA (AT2G08250), } \\
\text { AtSWEET4 (AT3G28007) }\end{array}$ \\
\hline miR852 & $\begin{array}{l}\text { IAA-leucine resistant (ILR)-like 1(AT5G56650); IAA-leucine resistant (ILR)-like 2 (AT5G56660); TIR1, } \\
\text { F-box/RNI-like superfamily protein (AT3G62980); K+ transporter 1 (AT2G26650); H(+)-ATPase } 11 \\
\text { (AT5G62670) }\end{array}$ \\
\hline
\end{tabular}

\section{6. miR169/NF-YA Module Is Altered in slr1 under Low-Temperature Stress}

To understand the biological significance of the RNAseq results, we selected one of the potential miR candidates, miR169, which is evolutionarily conserved, reported to be present in various plant species including monocots, dicots, ferns, and gymnosperms [68-70], and has been shown to be a central regulator of various abiotic stresses, including drought, salt, cold, heat, oxidative, and hypoxic stresses [71]. The miR169 family of Arabidopsis has 14 members that mature into four types of different isoforms, differing only by one or two nucleotides [71]. Phylogenetic analysis of miR169 revealed 
that apart from miR169a, b, c, and h, there are three obvious clades: clade I (mir169d, e, f, g), clade II (miR169i, k, m), and clade III (miR169j, l, n) [71]. The miR169 family members show distinct temporal and differential expression patterns and thus regulate diverse target genes [71,72]. One of the major targets of miR169 for abiotic stress response is nuclear factor $\mathrm{Y}(\mathrm{NF}-\mathrm{Y})$, a heterotrimeric transcription factor composed of NF-YA, NF-YB, and NF-YC proteins [73]. The link of the NF-Y family members in regulating plant developmental and stress response pathways has been demonstrated in several studies [73-81]. Earlier, a direct effect of temperature on miR169h and NF-YA was demonstrated [82]. miR169h abundance is directly influenced by temperature; while the abundance was high at high temperature, the abundance was considerably low at low temperature. As expected, miR169 target gene NF-YA expression was reciprocal to the abundance of the miR169 expression [82]. They further demonstrated that the NF-Y complex regulates the temperature-dependent flowering and petiole length through directly binding to the promoters of flowering regulator $F T$ and the auxin biosynthesis gene YUC2. These results make an elegant model linking miR169, NF-Y, and auxin. We tested whether a similar module works for cold stress response in slr1. For better clarification of the role of the miR169 family, we selected at least one member from each clade, as well as miR169a, b, and h. Besides miR169m, in cold-stressed $\operatorname{slr} 1$, all the tested miR169 members showed either a significant reduction in expression (miR169a, miR169d, miR169e, mir169h) or no changes in expression (miR169b, miR169g) (Figure 8). The expression data suggest that among miR169 family members, miR169a, miR169d, and miR169h function as major regulators linking auxin response and cold.

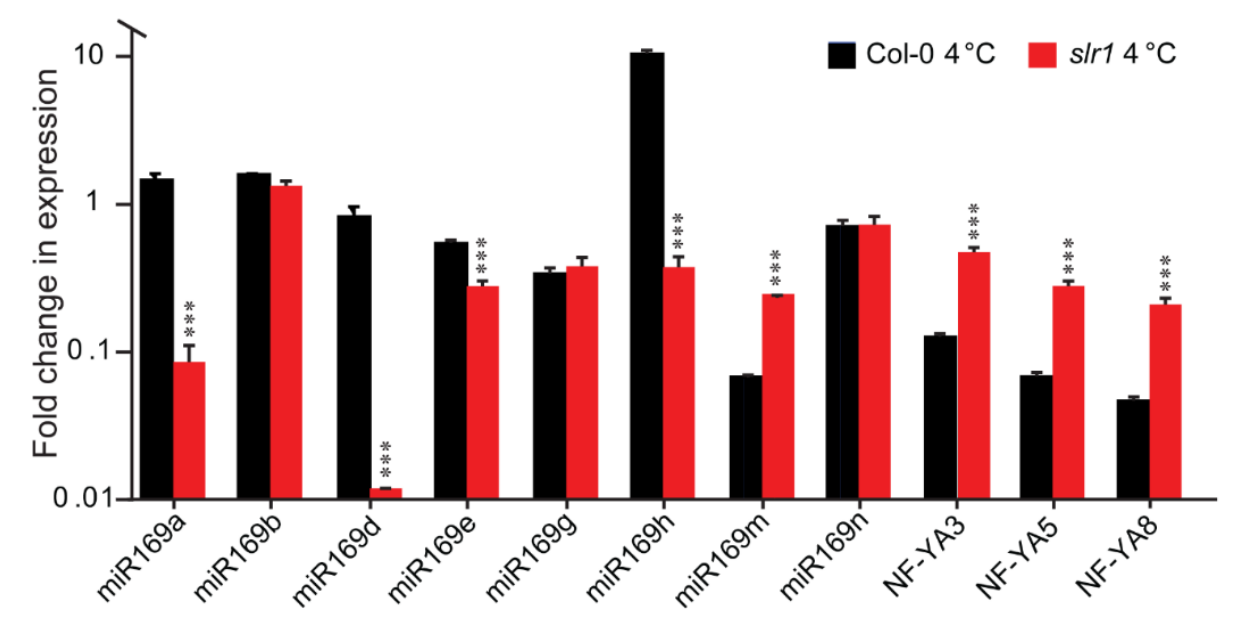

Figure 8. Relative expression of miR169 precursors and NF-YA3, NF-YA5, and NF-YA8 in Col-0 and slr 1 after $12 \mathrm{~h}$ of cold $\left(4^{\circ} \mathrm{C}\right)$ stress. Vertical bars represent the mean $\pm \mathrm{SE}$ of three biological replicates. Asterisks denote the statistical significance between the Col- 0 and $\operatorname{sir} 1$ at $4{ }^{\circ} \mathrm{C}$ as judged by the Student's $t$-test $\left.{ }^{* * *} p<0.001\right)$.

Next, we investigated whether the cold-stress-induced change in miR169 affects the NF-YA abundance reciprocally. In the wild type (Col-0), under cold stress, we observed a decrease in NF-YA abundance (8-, 15-, and 22-fold decreases compared with $23{ }^{\circ} \mathrm{C}$ for NF-YA3, NF-YA5, and NF-YA8, respectively), while in $\operatorname{slr} 1$, there was a higher accumulation of $N F-Y A$ transcripts compared with the wild type (3.94-, 4.3-, and 4.4-fold increases for NF-YA3, NF-YA5, and NF-YA8, respectively (Figure 8)). Based on the above findings, we speculate that the altered miR169/NF-YA module in slr1 possibly contributes to its cold-stress-susceptible phenotype. Further, the miR169/NF-YA module might play a pivotal role during cold stress recovery, and miR169 regulates the expression of this module in an SLR-dependent manner. 


\section{Discussion}

Several studies indicate that auxin and microRNAs play essential roles in plant cold stress response $[27,30,83-85]$. Auxin plays a pivotal role in regulating the temperature stress response, and high-temperature stress response directly affects the auxin biosynthesis through altering the expression of phytochrome interacting factors (PIFs) [86]. More recently, phytochromes have been shown to function as thermosensors in Arabidopsis [87,88]. Additionally, auxin transport and auxin signaling have also been shown to be altered in response to high temperature $[10,89,90]$. Under cold stress, polar and lateral auxin transports are altered, resulting in slower growth $[1,9,91]$. As for microRNAs, a large number of miRs have been implicated in regulating the low-temperature response in different plant species [30,92-95]. Although these studies represent links (1) between auxin and cold stress and (2) between miR and cold stress, the mechanistic link between microRNA and auxin in regulating plant cold stress response remains elusive. Here we report that (1) the downstream auxin signaling response is crucial for miR-mediated cold stress response in Arabidopsis root, (2) the loss of auxin response resulted in altered expression of specific miRs under cold stress, (3) the hypersensitive response of $\operatorname{slr} 1$ to cold stress is possibly linked to the differential expression of cold-regulated miRs, and (4) the miR169/NF-YA module possibly plays a major role in integrating auxin signaling, miR, and cold stress.

Intracellular auxin response and miR-mediated gene expression tightly regulate the root growth developmental process in plants. For instance, root elongation is inhibited by the accumulation of auxin in the cell elongation zone [96]. Similarly, the timely regulation of expression of several genes by $\mathrm{miR}$ is indispensable for proper root growth $[97,98]$. It was previously reported that the cold-induced inhibition of root growth is linked to the accumulation of auxin in the root meristematic zone, which results from the GNOM-regulated dysfunction of auxin efflux carrier, PIN2 [9]. In rice, genes linked to auxin signaling such as $A u x / I A A$ and $A R F$ were found to be altered by cold stress [16,17]. Consistently, in our current screening, we found $\operatorname{sir} 1$ to show a hypersensitive response to cold treatment during the root elongation recovery process. SLR encodes IAA14 protein, which functions as a repressor for auxin-induced gene expression, and a downstream auxin signaling component [56]. Mutation in slr1 results in stable IAA14 protein, which does not degrade in response to IAA, resulting in auxin insensitivity [99]. The finding that $\operatorname{sl} 1$ shows a hypersensitive response to cold stress indicates the importance of the downstream auxin signaling pathway in the process.

miR modulates the plant development, plant response to various environmental challenges, and auxin response by regulating the gene expression post-transcriptionally. From the beginning of plant miR study, its role in low-temperature and other stresses has been reported [25,100-102]. Previous studies suggest that during stress conditions, an increase in miR expression deregulates the negative regulators of stress. In contrast, a decrease in miR expression leads to the accumulation of positive regulators of stress $[103,104]$. The significant reduction in the expression of several miRs in the slr1 mutant compared to the wild type suggests that there could be an increased activity of negative regulators in the mutant leading to a susceptible phenotype (Table 3). The observed differences in post-transcriptional regulation of NF-YA transcripts by miR169 in wild type and slr1 under cold stress supports this notion (Figure 8). The miR169/NF-YA module, which is one of the stress-regulated miR target modules, showed an altered expression pattern in $\operatorname{slr} 1$ under cold stress. Our results demonstrate that $\mathrm{miR} 169 \mathrm{a}, \mathrm{miR} 169 \mathrm{~d}$, and miR169h are the primary targets of cold in the slr1 mutant (Figure 8). This is consistent with the idea that the temporal and differential expressions of the members within the same microRNA family widely varies depending on the growth stages and acquired stresses [105]. miR169m showed a completely opposite expression pattern in slr1 under cold stress compared to other members. This is interesting, but the significance of this result is unknown at present. The reduced expression of miR169a, miR169d, and miR169h directly influenced the expression of NF-YA transcripts, resulting in higher accumulation in $s l r 1$ than in the wild type under cold stress (Figure 8). The miR169/NF-YA module has already been shown to be linked to the regulation of the temperature response in previous studies $[82,106,107]$. In addition, NF-YA has been shown to 
modulate auxin response by regulating its biosynthesis [82]. Taken together, these findings suggest that the miR169/NF-YA module, which functions in an SLR/IAA14-dependent manner, could function as a major regulator integrating auxin, $\mathrm{miR}$, and cold stress response.

Besides miR169, several other miRs may be involved in regulating the auxin-mediated cold stress response. Low-temperature stress also significantly decreased the expression of miR390 in slr1 mutant compared to the wild type. miR390 has been suggested to direct the production of tasiRNAs from trans-acting siRNA3 (TAS3) transcripts, which regulate the ARF genes essential for auxin signaling [108]. Recently, it has been demonstrated that the miR390/TAS3/ARFs module plays a key role in regulating lateral root development in salt-stressed poplar through modulating the auxin pathway [109]. Moreover, miR390b-3p targets AtVps11, an essential component for endosome organization, intracellular protein transport, vacuole biogenesis, and pollen tube growth [110]. It also targets clathrin heavy chains, which mediate endocytosis and intracellular transport and are required for proper polar distribution of PINs [111]. Differentially regulated miR390 in wild type and slr1 under low-temperature stress may also link auxin signaling and miRs during the low-temperature stress response.

The essential amino acid tryptophan (Trp) is well known for its requirement in auxin biosynthesis. The plant needs Trp for the synthesis of various proteins and many metabolites. Interference in $\operatorname{Trp}$ biosynthesis leads to various developmental defects in plants [112]. The targeting of tryptophan synthetase by miR5642 under low temperature suggests possible crosstalk of low temperature and auxin biosynthesis during the cold stress response. Moreover, the miR774a, which targets several F-box proteins, could also attenuate the auxin signaling as several F-box proteins play indispensable roles in auxin signaling and response [113]. Taken together, these results confirm a complex triangular relation of $\mathrm{miR}$, cold, and auxin response.

Intriguingly, the differentially regulated miRs target a wide range of proteins involved in response to the stimulus, developmental processes, cellular component organization and biogenesis, biological regulation, cellular processes, metabolic processes, and stress signaling (Supplementary Table S1, Figure 7). Although many of the proteins targeted by specific miRs are still functionally not characterized, few of the target proteins have already been reported for their role in regulating various processes, including abiotic stresses such as cold $[30,104]$. Characterization of the other target proteins in this list will reveal the functional significance of these altered miRs in integrating auxin response and cold stress.

In agreement with the notion that the miRs are often expressed at a lower level, the majority of the novel miRs displayed a lower expression compared to known miRs (Supplementary Table S2). As per miRBase 22.1, these miRs have not been described previously in Arabidopsis, which could be due to their low, nondetectable expression level. In the present study, we possibly discovered most of the miRs in Arabidopsis during cold stress. The novel predicted miRs and known miRs, namely miR5656, miR774a, and miR8181, that show altered expression patterns in wild type and slr1 target the transposable elements (TEs) and transposons (Table 5 and Supplementary Table S2). TEs can have a myriad of effects when they are inserted into new locations [114-116]. These effects vary depending on the sequence of the TE and the precise location of its insertion. TEs are also responsive and susceptible to environmental changes. Stress-activated TEs might generate the raw diversity that species require over evolutionary time to survive stressful situations [117]. From bacteria to mammals, TE-induced mutations are associated with environmental adaptations (for a review, see the work of E. Casacuberta and J. Gonzalez [117]). In plants, TE-induced mutations result in adaptation to high altitude in soybean, adaptation to changing light environment in Arabidopsis, and adaptation to a wide range of environments in wheat [118-121]. Interestingly, TEs have also been shown to contribute to duplication of $A u x / I A A$ genes in soybean [122]. The findings that the cold stress stimulates miRs that potentially target TEs in slr1 suggest a possible involvement of TEs in integrating auxin and cold stress responses and need further studies. 


\section{Materials and Methods}

\subsection{Plant Materials and Growth Condition}

All lines are in the Columbia background of Arabidopsis thaliana (L.) Heynh., and Col-0 plants were used as wild type in the present study. axr1-3, aux1-7, eir1-1; pin3-3, pin4-3, and tir1-1 were obtained from the Arabidopsis Biological Resource Center (Columbus, OH, USA). afb2-1 was a kind gift of Nihal Dharmasiri (Texas State University, San Marcos, TX, USA). slr1 was described in Fukaki et al. (2002) [56].

Surface-sterilized seeds were placed in round, 9-cm Petri plates on modified Hoagland medium $[1,9,123]$ containing $1 \%(w / v)$ sucrose and $1 \%(w / v)$ agar. The plates were kept at $4{ }^{\circ} \mathrm{C}$ in the dark for 2 days for seed stratification. After stratification, the plates were transferred to the growth chamber (LPH-220S, NK System, Japan) at $23{ }^{\circ} \mathrm{C}$ under continuous white fluorescent light at an intensity of $100 \mu \mathrm{mol} \mathrm{m} \mathrm{m}^{-2} \mathrm{~s}^{-1}$, and seedlings were grown vertically for 5 days.

\subsection{Cold Stress Treatment and Analysis of Root Growth Recovery}

Cold stress treatment and growth recovery were performed as described earlier [9]. A $12 \mathrm{~h}$ cold treatment at $4{ }^{\circ} \mathrm{C}$ typically results in approximately $40-50 \%$ root elongation inhibition during the recovery phase at $23{ }^{\circ} \mathrm{C}$ [9]. Hence, we selected $12 \mathrm{~h}$ incubation at $4{ }^{\circ} \mathrm{C}$ as an optimal treatment for analyzing the effect of cold stress. Briefly, 5-day-old seedlings were transferred to new plates containing the modified Hoagland medium and kept at $4^{\circ} \mathrm{C}$ for $12 \mathrm{~h}$ in the growth chamber (NK System; LH-1-120.S). After cold stress, plates were put back at $23{ }^{\circ} \mathrm{C}$ for recovery, whereas the control plates were kept continuously at $23^{\circ} \mathrm{C}$. Percentage root elongation recovery compared to control (grown at $23{ }^{\circ} \mathrm{C}$ ) of each genotype was used as a measure of screening. The experiments were repeated at least three times, with eight seedlings per treatment. To measure cold stress recovery, seedlings were photographed by a digital camera (Canon Power Shot A640, Canon, Tokyo, Japan), and root growth recovery was analyzed by ImageJ1.47t software (http://rsbweb.nih.gov/ij/).

\subsection{Chemicals}

Difco Bacto Agar was purchased from BD Biosciences, San Jose, CA, USA. Other chemicals were from Wako Pure Chemical Industries, Osaka, Japan.

\subsection{Small RNA Isolation and Sequencing}

After 5-day-old seedlings grown on modified Hoagland media were cold-treated at $4{ }^{\circ} \mathrm{C}$ for $12 \mathrm{~h}$ or grown at $23{ }^{\circ} \mathrm{C}$ as control, their root tissues were used to construct small RNA libraries. Briefly, the total RNA was isolated from the roots of cold-stress-treated and control samples by using the RNeasy Kit (Qiagen, MD, USA) according to the manufacturer's instructions, and small RNA was enriched by RNeasy MinElute Cleanup kit (Qiagen, MD, USA). Eppendorf BioPhotometer plus (Hamburg, Germany) was used to detect the quality and the concentration of RNA. Construction of the sRNA libraries and deep sequencing were carried out by BGI (Beijing, China). Briefly, RNA with lengths of 16-36 nt was separated and purified using denaturing polyacrylamide gel electrophoresis, followed by sequential 3' and 5' RNA adaptor ligation to the small RNAs using T4 RNA Ligase. The adaptor-ligated samples were then reverse transcribed and amplified by PCR to construct the final libraries. Eight small RNA libraries - four from the wild type (two each from $23^{\circ} \mathrm{C}$ and $4{ }^{\circ} \mathrm{C}$ ) and four from auxin mutant slr1 (two each from $23^{\circ} \mathrm{C}$ and $4^{\circ} \mathrm{C}$ )-were prepared and subjected to high-throughput sequencing on Illumina platform (Illumina HiSeq 4000 platform, Illumina, San Diego, CA, USA). The sequencing resulted a total of $270,303,139$ reads $\left(47,318,921\right.$ and $39,919,856$ reads from Col- 0 at $23{ }^{\circ} \mathrm{C} ; 30,230,648$ and 23,124,483 reads from Col- 0 at $4{ }^{\circ} \mathrm{C} ; 22,247,497$ and $43,063,180$ reads from slr 1 at $23{ }^{\circ} \mathrm{C} ; 25,807,408$ and $45,591,146$ reads from $\operatorname{slr} 1$ at $\left.4^{\circ} \mathrm{C}\right)$. 


\subsection{Data Deposition Information}

The sequencing data that support the findings of this study have been deposited in the NCBI SRA database with the SRA accession code PRJNA579274. The SRA record is accessible through the following link: https://www.ncbi.nlm.nih.gov/sra/PRJNA579274.

\subsection{Bioinformatic Analysis of the sRNA Sequencing Data}

After sequencing, the raw reads were filtered, and adapter sequences were removed along with contamination and low-quality reads from raw reads. The remaining unique sequences (clean reads) were then processed to identify known and novel microRNAs.

Known miRs from Arabidopsis root after cold stress were identified using CLC Genomics Workbench v12.0 (CLC Bio, Aarhus, Denmark). Briefly, clean reads processed from raw sequencing reads after trimming adaptor sequences and removing low-quality reads were further analyzed by CLC workbench to extract and group sRNA. Sequences shorter than $16 \mathrm{nt}$ and larger than $36 \mathrm{nt}$ along with noncoding RNA such as rRNA, tRNA, and snRNA were excluded from further analysis. The remaining reads were and then annotated to identify the known Arabidopsis miRs. To identify known miRs, small RNA sequences were annotated against miRBase 22.1 (http://www.mirbase.org/index.shtml) using CLC Genomics Workbench 12.0 based on their sequence homology. Finally, the mapped miRs were obtained, which then were normalized using the reads per million reads (RPM) method. Normalized reads were then used to determine the fold change between the control and stressed samples.

Novel miRs were identified by using mirDeep-P, a plant-specific miR identification pipeline [124]. Briefly, for each sequenced small RNA library, reads were filtered by length, and only those between 16 and 36 nt were retained. FASTA-formatted reads were then analyzed by miRDeep-P using the Arabidopsis genome as a reference.

\subsection{Prediction of miR Targets}

The targets of identified miRs were predicted using psRNATarget (the plant small RNA target server, 2011 release; http://plantgrn.noble.org/psRNATarget/) by aligning with Arabidopsis transcripts and default parameters which included a threshold cut-off of 3.0, a complementarity scoring length of $20 \mathrm{bp}$, and the energy required for target accessibility equal to $25 \mathrm{kcal} / \mathrm{mole}$.

\subsection{Quantitative RT-PCR Validation of Selected Differentially Expressed miRs}

Analysis of miR expression was performed using the poly(T) adaptor RT-PCR method by Mir-X miR First-Strand Synthesis kit (Clonetech, Takara Bio, Moutain View, CA, USA) as per manufacturer's instruction. Briefly, for polyadenylation and cDNA synthesis, $1 \mu \mathrm{g}$ of DNaseI-treated total RNA was incubated at $37^{\circ} \mathrm{C}$ for $60 \mathrm{~min}$ in a $10 \mu \mathrm{L}$ reaction volume containing $\mathrm{mRQ}$ enzyme, and then the reaction was terminated at $85^{\circ} \mathrm{C}$ for $5 \mathrm{~min}$ to inactivate the enzymes. Quantitative RT-PCR (qRT-PCR) was run on a TaKaRa Dice Real-Time apparatus (Takara, Shiga, Japan) with the SYBR Green I Master kit (Bio-Rad, Hercules, CA, USA). The reaction conditions for qRT-PCR included the following steps: $10 \mathrm{~s}$ at $95{ }^{\circ} \mathrm{C}$ followed by 40 cycles of denaturation for $10 \mathrm{~s}$ at $95^{\circ} \mathrm{C}$ and annealing for $20 \mathrm{~s}$ at $60{ }^{\circ} \mathrm{C}$, and extension for $15 \mathrm{~s}$ at $72{ }^{\circ} \mathrm{C}$. miRs were quantified using specific primer pairs with the translation initiation factor elongation factor $1-\alpha(E F 1 \alpha)$ as the normalization control. Relative transcript abundance was calculated using the $2^{-\Delta \Delta C T}$ method [125]. All experiments were performed using three biological replicates and three technical replicates. The miR169 family primers were adapted from Serivichyaswat et al. [126]. All the primers used in the study are listed in Supplementary Table S4.

\subsection{Statistical Analysis}

Results are expressed as the means \pm SE from the appropriate number of experiments. A two-tailed Student's $t$-test was used to analyze statistical significance. 


\section{Conclusions}

The present study provides a basic platform to explore the genetic and cellular mechanisms by which auxin and miRs regulate the cold stress response. Identification of a handful of target miRs, including miR169, from the comparative RNA sequencing analyses between the wild type and the auxin signaling mutant $\operatorname{slr} 1$ indicates that auxin-regulated miRs play essential roles in maintaining the cellular signaling system to ensure an optimal cold stress response. Future overexpression or loss-of-function studies with the specific miRs that are altered in slr1 mutant and their targets will further clarify how the auxin- and miR-mediated pathways contribute to regulating the cold stress response.

Supplementary Materials: Supplementary Materials can be found at http://www.mdpi.com/1422-0067/21/22/ $8441 / \mathrm{s} 1$. Figure S1: Root phenotype of seedlings during $24 \mathrm{~h}$ recovery period after cold stress at $4{ }^{\circ} \mathrm{C}$ for $12 \mathrm{~h}$. Tick marks indicate the starting point of the recovery at $23^{\circ} \mathrm{C}$. Scale bar $=10 \mathrm{~mm}$. Figure S2: Novel miR expression profiles in the root of Col-0 and slr1. The heat map shows the hierarchical cluster analysis of novel miRs regulated in the cold-stressed root of Col- 0 and slr 1 . The color bars of the heatmap represent the gradient scale of normalized $\log 2-\mathrm{TPM}$ values for each miR. Red color indicates high levels of miRs abundance, and green color indicates low abundance. The analysis was performed using two independent biological replicates. Table S1: Expression of known miRs in small RNA libraries. Table S2: Expression of predicted miRs in small RNA libraries. Table S3: Details of novel miRs predicted in the present study. Table S4: List of primers used in the present study.

Author Contributions: Conceptualization, M.A., Y.Q. and A.R.; methodology, M.A. and K.S.; validation, investigation, and data curation, M.A. and A.R.; writing-original draft preparation, review and editing, M.A. and A.R.; funding acquisition, A.R. All authors have read and agreed to the published version of the manuscript.

Funding: This work was supported by KAKENHI grant from Japan Society for the Promotion Science (Grant numbers A15F151020 and 20H02945), and in part by the Iwate University grant for high-level research (to A.R.). M.A. was an International Research Fellow of the Japan Society for the Promotion of Science during the study.

Acknowledgments: We thank Beenish Fakher and Bello Hassan Jakada from Qin lab for their help in the experiment.

Conflicts of Interest: The authors declare no conflict of interest. The funders had no role in the design of the study; in the collection, analyses, or interpretation of data; in the writing of the manuscript; or in the decision to publish the results.

\section{Abbreviations}

$\begin{array}{ll}\text { miRs } & \text { MicroRNAs } \\ \text { qRT-PCR } & \text { Quantitative Real-Time PCR } \\ \text { EF1 } \alpha & \text { Elongation Factor 1- } \alpha \\ \text { TEs } & \text { Transposable Elements } \\ \text { nt } & \text { Nucleotide } \\ \text { IAA } & \text { Indole-3-aCetic Acid } \\ \text { ARF } & \text { Auxin Response Factor } \\ \text { QC } & \text { Quiescent Center } \\ \text { SIZ1 } & \text { SAP and MIZ1 domain-containing ligase1 } \\ \text { PIN } & \text { Pin-formed } \\ \text { SAUR } & \text { Small Auxin Upregulated RNA } \\ \text { GH } & \text { Gretchen Hagen }\end{array}$

\section{References}

1. Rahman, A. Auxin: A regulator of cold stress response. Physiol. Plant 2013, 147, 28-35. [CrossRef] [PubMed]

2. Sanghera, G.S.; Wani, S.H.; Hussain, W.; Singh, N.B. Engineering cold stress tolerance in crop plants. Curr. Genom. 2011, 12, 30-43. [CrossRef] [PubMed]

3. Yadav, S.K. Cold stress tolerance mechanisms in plants. A review. Agron. Sustain. Dev. 2010, 30, 515-527. [CrossRef]

4. Thakur, P.; Kumar, S.; Malik, J.A.; Berger, J.D.; Nayyar, H. Cold stress effects on reproductive development in grain crops: An overview. Environ. Exp. Bot. 2010, 67, 429-443. [CrossRef]

5. Chandler, J.W. Auxin as compère in plant hormone crosstalk. Planta 2009, 231, 1-12. [CrossRef] 
6. Davies, P.J. The plant hormones: Their nature, occurrence, and functions. In Plant Hormones: Biosynthesis, Signal Transduction, Action! Davies, P.J., Ed.; Springer: Dordrecht, The Netherlands, 2010; pp. 1-15. [CrossRef]

7. Gray, W.M.; Ostin, A.; Sandberg, G.; Romano, C.P.; Estelle, M. High temperature promotes auxin-mediated hypocotyl elongation in Arabidopsis. Proc. Natl. Acad. Sci. USA 1998, 95, 7197-7202. [CrossRef]

8. Koini, M.A.; Alvey, L.; Allen, T.; Tilley, C.A.; Harberd, N.P.; Whitelam, G.C.; Franklin, K.A. High temperature-mediated adaptations in plant architecture require the bHLH transcription factor PIF4. Curr. Biol. 2009, 19, 408-413. [CrossRef]

9. Shibasaki, K.; Uemura, M.; Tsurumi, S.; Rahman, A. Auxin response in Arabidopsis under cold stress: Underlying molecular mechanisms. Plant Cell 2009, 21, 3823-3838. [CrossRef]

10. Hanzawa, T.; Shibasaki, K.; Numata, T.; Kawamura, Y.; Gaude, T.; Rahman, A. Cellular auxin homeostasis under high temperature is regulated through a sorting NEXIN1-dependent endosomal trafficking pathway. Plant Cell 2013, 25, 3424-3433. [CrossRef]

11. Ashraf, M.A.; Rahman, A. Hormonal regulation of cold stress response. In Cold Tolerance in Plants: Physiological, Molecular and Genetic Perspectives; Wani, S.H., Herath, V., Eds.; Springer International Publishing: Cham, Switzerland, 2018; pp. 65-88. [CrossRef]

12. Hannah, M.A.; Heyer, A.G.; Hincha, D.K. A global survey of gene regulation during cold acclimation in Arabidopsis thaliana. PLoS Genet. 2005, 1, e26. [CrossRef]

13. Ashraf, M.A.; Rahman, A. Cold stress response in Arabidopsis thaliana is mediated by GNOM ARF-GEF. Plant J. 2019, 97, 500-516. [CrossRef] [PubMed]

14. Hong, J.H.; Savina, M.; Du, J.; Devendran, A.; Kannivadi Ramakanth, K.; Tian, X.; Sim, W.S.; Mironova, V.V.; Xu, J. A sacrifice-for-survival mechanism protects root stem cell niche from chilling stress. Cell 2017, 170, 102-113.e14. [CrossRef] [PubMed]

15. Du, H.; Liu, H.; Xiong, L. Endogenous auxin and jasmonic acid levels are differentially modulated by abiotic stresses in rice. Front. Plant Sci. 2013, 4, 397. [CrossRef] [PubMed]

16. Zhao, J.; Zhang, S.; Yang, T.; Zeng, Z.; Huang, Z.; Liu, Q.; Wang, X.; Leach, J.; Leung, H.; Liu, B. Global transcriptional profiling of a cold-tolerant rice variety under moderate cold stress reveals different cold stress response mechanisms. Physiol Plant 2015, 154, 381-394. [CrossRef]

17. Jain, M.; Khurana, J.P. Transcript profiling reveals diverse roles of auxin-responsive genes during reproductive development and abiotic stress in rice. FEBS J. 2009, 276, 3148-3162. [CrossRef]

18. Du, H.; Wu, N.; Fu, J.; Wang, S.; Li, X.; Xiao, J.; Xiong, L. A GH3 family member, OsGH3-2, modulates auxin and abscisic acid levels and differentially affects drought and cold tolerance in rice. J. Exp. Bot. 2012, 63, 6467-6480. [CrossRef]

19. Miura, K.; Jin, J.B.; Lee, J.; Yoo, C.Y.; Stirm, V.; Miura, T.; Ashworth, E.N.; Bressan, R.A.; Yun, D.J.; Hasegawa, P.M. SIZ1-mediated sumoylation of ICE1 controls CBF3/DREB1A expression and freezing tolerance in Arabidopsis. Plant Cell 2007, 19, 1403-1414. [CrossRef]

20. Miura, K.; Lee, J.; Gong, Q.; Ma, S.; Jin, J.B.; Yoo, C.Y.; Miura, T.; Sato, A.; Bohnert, H.J.; Hasegawa, P.M. SIZ1 regulation of phosphate starvation-induced root architecture remodeling involves the control of auxin accumulation. Plant Physiol. 2011, 155, 1000-1012. [CrossRef]

21. Dong, C.H.; Hu, X.; Tang, W.; Zheng, X.; Kim, Y.S.; Lee, B.H.; Zhu, J.K. A putative Arabidopsis nucleoporin, AtNUP160, is critical for RNA export and required for plant tolerance to cold stress. Mol. Cell Biol. 2006, 26, 9533-9543. [CrossRef]

22. Parry, G.; Ward, S.; Cernac, A.; Dharmasiri, S.; Estelle, M. The Arabidopsis SUPPRESSOR OF AUXIN RESISTANCE proteins are nucleoporins with an important role in hormone signaling and development. Plant Cell 2006, 18, 1590-1603. [CrossRef]

23. Bartel, D.P. MicroRNAs: Genomics, biogenesis, mechanism, and function. Cell 2004, 116, 281-297. [CrossRef]

24. Voinnet, O. Origin, biogenesis, and activity of plant microRNAs. Cell 2009, 136, 669-687. [CrossRef] [PubMed]

25. Karimi, M.; Ghazanfari, F.; Fadaei, A.; Ahmadi, L.; Shiran, B.; Rabei, M.; Fallahi, H. The small-RNA profiles of almond (Prunus dulcis Mill.) reproductive tissues in response to cold stress. PLoS ONE 2016, 11, e0156519. [CrossRef] [PubMed]

26. Shu, Y.; Liu, Y.; Li, W.; Song, L.; Zhang, J.; Guo, C. Genome-wide investigation of microRNAs and their targets in response to freezing stress in Medicago sativa L., based on high-throughput sequencing. G3 (Bethesda) 2016, 6, 755-765. [CrossRef] [PubMed] 
27. Song, G.; Zhang, R.; Zhang, S.; Li, Y.; Gao, J.; Han, X.; Chen, M.; Wang, J.; Li, W.; Li, G. Response of microRNAs to cold treatment in the young spikes of common wheat. BMC Genom. 2017, 18, 212. [CrossRef]

28. Tyczewska, A.; Gracz, J.; Kuczyński, J.; Twardowski, T. Deciphering the soybean molecular stress response via high-throughput approaches. Acta Biochim. Pol. 2016, 63, 631-643. [CrossRef]

29. Bej, S.; Basak, J. MicroRNAs: The potential biomarkers in plant stress response. Am. J. Plant Sci. 2014, 5, 748-759. [CrossRef]

30. Megha, S.; Basu, U.; Kav, N.N.V. Regulation of low temperature stress in plants by microRNAs. Plant Cell Environ. 2018, 41, 1-15. [CrossRef]

31. Sunkar, R.; Li, Y.F.; Jagadeeswaran, G. Functions of microRNAs in plant stress responses. Trends Plant Sci. 2012, 17, 196-203. [CrossRef]

32. Lv, D.K.; Bai, X.; Li, Y.; Ding, X.D.; Ge, Y.; Cai, H.; Ji, W.; Wu, N.; Zhu, Y.M. Profiling of cold-stress-responsive miRNAs in rice by microarrays. Gene 2010, 459, 39-47. [CrossRef]

33. Abdel-Ghany, S.E.; Pilon, M. MicroRNA-mediated systemic down-regulation of copper protein expression in response to low copper availability in Arabidopsis. J. Biol. Chem. 2008, 283, 15932-15945. [CrossRef] [PubMed]

34. Ma, C.; Burd, S.; Lers, A. miR408 is involved in abiotic stress responses in Arabidopsis. Plant J. 2015, 84, $169-187$. [CrossRef] [PubMed]

35. Dong, C.-H.; Pei, H. Over-expression of miR397 improves plant tolerance to cold stress in Arabidopsis thaliana. J. Plant Biol. 2014, 57, 209-217. [CrossRef]

36. Song, J.B.; Gao, S.; Wang, Y.; Li, B.W.; Zhang, Y.L.; Yang, Z.M. miR394 and its target gene LCR are involved in cold stress response in Arabidopsis. Plant Gene 2016, 5, 56-64. [CrossRef]

37. Wang, S.-T.; Sun, X.-L.; Hoshino, Y.; Yu, Y.; Jia, B.; Sun, Z.-W.; Sun, M.-Z.; Duan, X.-B.; Zhu, Y.-M. MicroRNA319 positively regulates cold tolerance by targeting OsPCF6 and OsTCP21 in rice (Oryza sativa L.). PLoS ONE 2014, 9, e91357. [CrossRef] [PubMed]

38. Yang, C.; Li, D.; Mao, D.; Liu, X.; Ji, C.; Li, X.; Zhao, X.; Cheng, Z.; Chen, C.; Zhu, L. Overexpression of microRNA319 impacts leaf morphogenesis and leads to enhanced cold tolerance in rice (Oryza sativa L.). Plant Cell Environ. 2013, 36, 2207-2218. [CrossRef]

39. Zhang, X.; Wang, W.; Wang, M.; Zhang, H.Y.; Liu, J.H. The miR396b of Poncirus trifoliata functions in cold tolerance by regulating ACC oxidase gene expression and modulating ethylene-polyamine homeostasis. Plant Cell Physiol. 2016, 57, 1865-1878. [CrossRef]

40. Bai, B.; Bian, H.; Zeng, Z.; Hou, N.; Shi, B.; Wang, J.; Zhu, M.; Han, N. miR393-mediated auxin signaling regulation is involved in root elongation inhibition in response to toxic aluminum stress in Barley. Plant Cell Physiol. 2017, 58, 426-439. [CrossRef]

41. Gray, W.M.; Kepinski, S.; Rouse, D.; Leyser, O.; Estelle, M. Auxin regulates SCF(TIR1)-dependent degradation of AUX/IAA proteins. Nature 2001, 414, 271-276. [CrossRef]

42. Jones-Rhoades, M.W.; Bartel, D.P. Computational identification of plant microRNAs and their targets, including a stress-induced miRNA. Mol. Cell 2004, 14, 787-799. [CrossRef]

43. Liu, Y.; Wang, K.; Li, D.; Yan, J.; Zhang, W. Enhanced cold tolerance and tillering in Switchgrass (Panicum virgatum L.) by heterologous expression of Osa-miR393a. Plant Cell Physiol. 2017, 58, 2226-2240. [CrossRef] [PubMed]

44. Meng, Y.; Chen, D.; Ma, X.; Mao, C.; Cao, J.; Wu, P.; Chen, M. Mechanisms of microRNA-mediated auxin signaling inferred from the rice mutant osaxr. Plant Signal. Behav. 2010, 5, 252-254. [CrossRef] [PubMed]

45. Wang, Y.; Li, K.; Chen, L.; Zou, Y.; Liu, H.; Tian, Y.; Li, D.; Wang, R.; Zhao, F.; Ferguson, B.J.; et al. MicroRNA167-directed regulation of the auxin response factors GmARF8a and GmARF8b is required for soybean nodulation and lateral root development. Plant Physiol. 2015, 168, 984-999. [CrossRef] [PubMed]

46. Lin, Y.; Lai, Z.; Tian, Q.; Lin, L.; Lai, R.; Yang, M.; Zhang, D.; Chen, Y.; Zhang, Z. Endogenous target mimics down-regulate miR160 mediation of ARF10, -16, and -17 cleavage during somatic embryogenesis in Dimocarpus longan Lour. Front. Plant Sci. 2015, 6, 956. [CrossRef]

47. Rhoades, M.W.; Reinhart, B.J.; Lim, L.P.; Burge, C.B.; Bartel, B.; Bartel, D.P. Prediction of plant microRNA targets. Cell 2002, 110, 513-520. [CrossRef]

48. Teotia, P.S.; Mukherjee, S.K.; Mishra, N.S. Fine tuning of auxin signaling by miRNAs. Physiol. Mol. Biol. Plants 2008, 14, 81-90. [CrossRef] 
49. Mallory, A.C.; Bartel, D.P.; Bartel, B. MicroRNA-directed regulation of Arabidopsis AUXIN RESPONSE FACTOR17 is essential for proper development and modulates expression of early auxin response genes. Plant Cell 2005, 17, 1360-1375. [CrossRef]

50. Zhang, Y.; Zeng, Z.; Chen, C.; Li, C.; Xia, R.; Li, J. Genome-wide characterization of the auxin response factor (ARF) gene family of Litchi (Litchi chinensis Sonn.): Phylogenetic analysis, miRNA regulation and expression changes during fruit abscission. PeerJ 2019, 7, e6677. [CrossRef]

51. Liu, H.; Jia, S.; Shen, D.; Liu, J.; Li, J.; Zhao, H.; Han, S.; Wang, Y. Four AUXIN RESPONSE FACTOR genes downregulated by microRNA167 are associated with growth and development in Oryza sativa. Funct. Plant Biol. 2012, 39, 736-744. [CrossRef]

52. Liu, N.; Wu, S.; Van Houten, J.; Wang, Y.; Ding, B.; Fei, Z.; Clarke, T.H.; Reed, J.W.; van der Knaap, E. Down-regulation of AUXIN RESPONSE FACTORS 6 and 8 by microRNA 167 leads to floral development defects and female sterility in tomato. J. Exp. Bot. 2014, 65, 2507-2520. [CrossRef]

53. Sanan-Mishra, N.; Varanasi, S.P.; Mukherjee, S.K. Micro-regulators of auxin action. Plant Cell Rep. 2013, 32, 733-740. [CrossRef] [PubMed]

54. Cai, H.; Yang, C.; Liu, S.; Qi, H.; Wu, L.; Xu, L.A.; Xu, M. MiRNA-target pairs regulate adventitious rooting in Populus: A functional role for miR167a and its target Auxin response factor 8. Tree Physiol. 2019, 39, 1922-1936. [CrossRef] [PubMed]

55. Guo, H.S.; Xie, Q.; Fei, J.F.; Chua, N.H. MicroRNA directs mRNA cleavage of the transcription factor NAC1 to downregulate auxin signals for Arabidopsis lateral root development. Plant Cell 2005, 17, 1376-1386. [CrossRef] [PubMed]

56. Fukaki, H.; Tameda, S.; Masuda, H.; Tasaka, M. Lateral root formation is blocked by a gain-of-function mutation in the SOLITARY-ROOT/IAA14 gene of Arabidopsis. Plant J. 2002, 29, 153-168. [CrossRef]

57. Dharmasiri, N.; Dharmasiri, S.; Estelle, M. The F-box protein TIR1 is an auxin receptor. Nature 2005, 435, 441-445. [CrossRef]

58. Leyser, H.M.; Lincoln, C.A.; Timpte, C.; Lammer, D.; Turner, J.; Estelle, M. Arabidopsis auxin-resistance gene AXR1 encodes a protein related to ubiquitin-activating enzyme E1. Nature 1993, 364, 161-164. [CrossRef]

59. Dharmasiri, N.; Dharmasiri, S.; Weijers, D.; Lechner, E.; Yamada, M.; Hobbie, L.; Ehrismann, J.S.; Jurgens, G.; Estelle, M. Plant development is regulated by a family of auxin receptor F box proteins. Dev. Cell 2005, 9, 109-119. [CrossRef]

60. Pickett, F.B.; Wilson, A.K.; Estelle, M. The aux1 mutation of Arabidopsis confers both auxin and ethylene resistance. Plant Physiol. 1990, 94, 1462-1466. [CrossRef]

61. Luschnig, C.; Gaxiola, R.A.; Grisafi, P.; Fink, G.R. EIR1, a root-specific protein involved in auxin transport, is required for gravitropism in Arabidopsis thaliana. Genes Dev. 1998, 12, 2175-2187. [CrossRef]

62. Friml, J.; Wisniewska, J.; Benkova, E.; Mendgen, K.; Palme, K. Lateral relocation of auxin efflux regulator PIN3 mediates tropism in Arabidopsis. Nature 2002, 415, 806-809. [CrossRef]

63. Friml, J.; Benkova, E.; Blilou, I.; Wisniewska, J.; Hamann, T.; Ljung, K.; Woody, S.; Sandberg, G.; Scheres, B.; Jurgens, G.; et al. AtPIN4 mediates sink-driven auxin gradients and root patterning in Arabidopsis. Cell 2002, 108, 661-673. [CrossRef]

64. Liu, Q.; Wang, F.; Axtell, M.J. Analysis of complementarity requirements for plant microRNA targeting using a Nicotiana benthamiana quantitative transient assay. Plant Cell 2014, 26, 741-753. [CrossRef] [PubMed]

65. Mallory, A.C.; Reinhart, B.J.; Jones-Rhoades, M.W.; Tang, G.; Zamore, P.D.; Barton, M.K.; Bartel, D.P. MicroRNA control of PHABULOSA in leaf development: Importance of pairing to the microRNA 5 ' region. EMBO J. 2004, 23, 3356-3364. [CrossRef] [PubMed]

66. Iwakawa, H.O.; Tomari, Y. Molecular insights into microRNA-mediated translational repression in plants. Mol. Cell 2013, 52, 591-601. [CrossRef] [PubMed]

67. Iwakawa, H.O.; Tomari, Y. The functions of microRNAs: mRNA decay and translational repression. Trends Cell Biol. 2015, 25, 651-665. [CrossRef] [PubMed]

68. Guo, Z.; Kuang, Z.; Wang, Y.; Zhao, Y.; Tao, Y.; Cheng, C.; Yang, J.; Lu, X.; Hao, C.; Wang, T.; et al. PmiREN: A comprehensive encyclopedia of plant miRNAs. Nucleic Acids Res. 2020, 48, D1114-D1121. [CrossRef]

69. Sunkar, R.; Jagadeeswaran, G. In silico identification of conserved microRNAs in large number of diverse plant species. BMC Plant Biol. 2008, 8, 37. [CrossRef]

70. Axtell, M.J.; Bartel, D.P. Antiquity of microRNAs and their targets in land plants. Plant Cell 2005, 17, $1658-1673$. [CrossRef] 
71. Li, Y.J.; Fu, Y.R.; Ji, L.S.; Wu, C.A.; Zheng, C.C. Characterization and expression analysis of the Arabidopsis miR169 family. Plant Sci. 2010, 178, 271-280. [CrossRef]

72. Rao, S.; Balyan, S.; Jha, S.; Mathur, S. Novel insights into expansion and functional diversification of MIR169 family in tomato. Planta 2020, 251, 55. [CrossRef]

73. Petroni, K.; Kumimoto, R.W.; Gnesutta, N.; Calvenzani, V.; Fornari, M.; Tonelli, C.; Holt, B.F., 3rd; Mantovani, R. The promiscuous life of plant NUCLEAR FACTOR Y transcription factors. Plant Cell 2012, 24, 4777-4792. [CrossRef] [PubMed]

74. Nelson, D.E.; Repetti, P.P.; Adams, T.R.; Creelman, R.A.; Wu, J.; Warner, D.C.; Anstrom, D.C.; Bensen, R.J.; Castiglioni, P.P.; Donnarummo, M.G.; et al. Plant nuclear factor Y (NF-Y) B subunits confer drought tolerance and lead to improved corn yields on water-limited acres. Proc. Natl. Acad. Sci. USA 2007, 104, 16450-16455. [CrossRef]

75. Ma, X.J.; Yu, T.F.; Li, X.H.; Cao, X.Y.; Ma, J.; Chen, J.; Zhou, Y.B.; Chen, M.; Ma, Y.Z.; Zhang, J.H.; et al. Overexpression of GmNFYA5 confers drought tolerance to transgenic Arabidopsis and soybean plants. BMC Plant Biol. 2020, 20, 123. [CrossRef]

76. Lee, D.K.; Kim, H.I.; Jang, G.; Chung, P.J.; Jeong, J.S.; Kim, Y.S.; Bang, S.W.; Jung, H.; Choi, Y.D.; Kim, J.K. The NF-YA transcription factor OsNF-YA7 confers drought stress tolerance of rice in an abscisic acid independent manner. Plant Sci. 2015, 241, 199-210. [CrossRef] [PubMed]

77. Ni, Z.; Hu, Z.; Jiang, Q.; Zhang, H. GmNFYA3, a target gene of miR169, is a positive regulator of plant tolerance to drought stress. Plant Mol. Biol. 2013, 82, 113-129. [CrossRef] [PubMed]

78. Zhao, B.T.; Ge, L.F.; Liang, R.Q.; Li, W.; Ruan, K.C.; Lin, H.X.; Jin, Y.X. Members of miR-169 family are induced by high salinity and transiently inhibit the NF-YA transcription factor. BMC Mol. Biol. 2009, 10. [CrossRef] [PubMed]

79. Luan, M.; Xu, M.; Lu, Y.; Zhang, L.; Fan, Y.; Wang, L. Expression of Zma-miR169 miRNAs and their target ZmNF-YA genes in response to abiotic stress in maize leaves. Gene 2015, 555, 178-185. [CrossRef]

80. Du, Q.; Zhao, M.; Gao, W.; Sun, S.; Li, W.X. microRNA/microRNA* complementarity is important for the regulation pattern of NFYA5 by miR169 under dehydration shock in Arabidopsis. Plant J. 2017, 91, $22-33$. [CrossRef]

81. Li, W.X.; Oono, Y.; Zhu, J.; He, X.J.; Wu, J.M.; Iida, K.; Lu, X.Y.; Cui, X.; Jin, H.; Zhu, J.K. The Arabidopsis NFYA5 transcription factor is regulated transcriptionally and posttranscriptionally to promote drought resistance. Plant Cell 2008, 20, 2238-2251. [CrossRef]

82. Gyula, P.; Baksa, I.; Toth, T.; Mohorianu, I.; Dalmay, T.; Szittya, G. Ambient temperature regulates the expression of a small set of sRNAs influencing plant development through NF-YA2 and YUC2. Plant Cell Environ. 2018, 41, 2404-2417. [CrossRef]

83. Eremina, M.; Rozhon, W.; Poppenberger, B. Hormonal control of cold stress responses in plants. Cell Mol. Life Sci. 2016, 73, 797-810. [CrossRef] [PubMed]

84. Tang, Z.; Zhang, L.; Xu, C.; Yuan, S.; Zhang, F.; Zheng, Y.; Zhao, C. Uncovering small RNA-mediated responses to cold stress in a wheat thermosensitive genic male-sterile line by deep sequencing. Plant Physiol. 2012, 159, 721-738. [CrossRef] [PubMed]

85. Zhou, X.; Wang, G.; Sutoh, K.; Zhu, J.K.; Zhang, W. Identification of cold-inducible microRNAs in plants by transcriptome analysis. Biochim. Biophys Acta 2008, 1779, 780-788. [CrossRef] [PubMed]

86. Sun, J.; Qi, L.; Li, Y.; Chu, J.; Li, C. PIF4-mediated activation of YUCCA8 expression integrates temperature into the auxin pathway in regulating Arabidopsis hypocotyl growth. PLoS Genet. 2012, 8, e1002594. [CrossRef]

87. Jung, J.H.; Domijan, M.; Klose, C.; Biswas, S.; Ezer, D.; Gao, M.; Khattak, A.K.; Box, M.S.; Charoensawan, V.; Cortijo, S.; et al. Phytochromes function as thermosensors in Arabidopsis. Science 2016, 354, 886-889. [CrossRef]

88. Fiorucci, A.-S.; Galvão, V.C.; Ince, Y.Ç.; Boccaccini, A.; Goyal, A.; Allenbach Petrolati, L.; Trevisan, M.; Fankhauser, C. PHYTOCHROME INTERACTING FACTOR 7 is important for early responses to elevated temperature in Arabidopsis seedlings. New Phytol. 2020, 226, 50-58. [CrossRef]

89. Wang, R.; Zhang, Y.; Kieffer, M.; Yu, H.; Kepinski, S.; Estelle, M. Corrigendum: HSP90 regulates temperature-dependent seedling growth in Arabidopsis by stabilizing the auxin co-receptor F-box protein TIR1. Nat. Commun. 2016, 7, 11677. [CrossRef] 
90. Bawa, G.; Feng, L.; Chen, G.; Chen, H.; Hu, Y.; Pu, T.; Cheng, Y.; Shi, J.; Xiao, T.; Zhou, W.; et al. Gibberellins and auxin regulate soybean hypocotyl elongation under low light and high-temperature interaction. Physiol. Plant 2020. [CrossRef]

91. Nadella, V.; Shipp, M.J.; Muday, G.K.; Wyatt, S.E. Evidence for altered polar and lateral auxin transport in the gravity persistent signal (gps) mutants of Arabidopsis. Plant Cell Environ. 2006, 29, 682-690. [CrossRef]

92. Liu, Q.; Yan, S.; Yang, T.; Zhang, S.; Chen, Y.Q.; Liu, B. Small RNAs in regulating temperature stress response in plants. J. Integr. Plant Biol. 2017, 59, 774-791. [CrossRef]

93. Yang, Y.; Zhang, X.; Su, Y.; Zou, J.; Wang, Z.; Xu, L.; Que, Y. miRNA alteration is an important mechanism in sugarcane response to low-temperature environment. BMC Genom. 2017, 18, 833. [CrossRef] [PubMed]

94. Cao, X.; Wu, Z.; Jiang, F.; Zhou, R.; Yang, Z. Identification of chilling stress-responsive tomato microRNAs and their target genes by high-throughput sequencing and degradome analysis. BMC Genom. 2014, 15, 1130. [CrossRef] [PubMed]

95. Jian, X.; Zhang, L.; Li, G.; Wang, X.; Cao, X.; Fang, X.; Chen, F. Identification of novel stress-regulated microRNAs from Oryza sativa L. Genomics 2010, 95, 47-55. [CrossRef] [PubMed]

96. Rahman, A.; Bannigan, A.; Sulaman, W.; Pechter, P.; Blancaflor, E.B.; Baskin, T.I. Auxin, actin and growth of the Arabidopsis thaliana primary root. Plant J. 2007, 50, 514-528. [CrossRef] [PubMed]

97. Gutierrez, L.; Bussell, J.D.; Pacurar, D.I.; Schwambach, J.; Pacurar, M.; Bellini, C. Phenotypic plasticity of adventitious rooting in Arabidopsis is controlled by complex regulation of AUXIN RESPONSE FACTOR transcripts and microRNA abundance. Plant Cell 2009, 21, 3119-3132. [CrossRef]

98. Li, C.; Zhang, B. MicroRNAs in control of plant development. J. Cell Physiol. 2016, 231, 303-313. [CrossRef]

99. Fukaki, H.; Nakao, Y.; Okushima, Y.; Theologis, A.; Tasaka, M. Tissue-specific expression of stabilized SOLITARY-ROOT/IAA14 alters lateral root development in Arabidopsis. Plant J. 2005, 44, 382-395. [CrossRef]

100. Kumar, R. Role of microRNAs in biotic and abiotic stress responses in crop plants. Appl. Biochem. Biotechnol. 2014, 174, 93-115. [CrossRef]

101. Sunkar, R.; Zhu, J.K. Novel and stress-regulated microRNAs and other small RNAs from Arabidopsis. Plant Cell 2004, 16, 2001-2019. [CrossRef]

102. Sun, X.; Lin, L.; Sui, N. Regulation mechanism of microRNA in plant response to abiotic stress and breeding. Mol. Biol. Rep. 2019, 46, 1447-1457. [CrossRef]

103. Sunkar, R.; Chinnusamy, V.; Zhu, J.; Zhu, J.K. Small RNAs as big players in plant abiotic stress responses and nutrient deprivation. Trends Plant Sci. 2007, 12, 301-309. [CrossRef] [PubMed]

104. Sharma, R.; Upadhyay, S.; Bhat, B.; Singh, G.; Bhattacharya, S.; Singh, A. Abiotic stress induced miRNA-TF-gene regulatory network: A structural perspective. Genomics 2020, 112, 412-422. [CrossRef] [PubMed]

105. Baker, C.C.; Sieber, P.; Wellmer, F.; Meyerowitz, E.M. The early extra petals1 mutant uncovers a role for microRNA miR164c in regulating petal number in Arabidopsis. Curr. Biol. 2005, 15, 303-315. [CrossRef] [PubMed]

106. Shi, H.; Chan, Z.L. AtHAP5A modulates freezing stress resistance in Arabidopsis independent of the CBF pathway. Plant Signal. Behav. 2014, 9, e29109. [CrossRef]

107. Shi, H.; Ye, T.; Zhong, B.; Liu, X.; Jin, R.; Chan, Z. AtHAP5A modulates freezing stress resistance in Arabidopsis through binding to CCAAT motif of AtXTH21. New Phytol. 2014, 203, 554-567. [CrossRef]

108. Lin, Y.; Lin, L.; Lai, R.; Liu, W.; Chen, Y.; Zhang, Z.; XuHan, X.; Lai, Z. MicroRNA390-directed TAS3 cleavage leads to the production of tasiRNA-ARF3/4 during somatic embryogenesis in Dimocarpus longan Lour. Front. Plant Sci. 2015, 6, 1119. [CrossRef]

109. He, F.; Xu, C.; Fu, X.; Shen, Y.; Guo, L.; Leng, M.; Luo, K. The MicroRNA390/TRANS-ACTING SHORT INTERFERING RNA3 module mediates lateral root growth under salt stress via the auxin pathway. Plant Physiol. 2018, 177, 775-791. [CrossRef]

110. Tan, X.; Wei, J.; Li, B.; Wang, M.; Bao, Y. AtVps11 is essential for vacuole biogenesis in embryo and participates in pollen tube growth in Arabidopsis. Biochem. Biophys. Res. Commun. 2017, 491, 794-799. [CrossRef]

111. Kitakura, S.; Vanneste, S.; Robert, S.; Lofke, C.; Teichmann, T.; Tanaka, H.; Friml, J. Clathrin mediates endocytosis and polar distribution of PIN auxin transporters in Arabidopsis. Plant Cell 2011, 23, 1920-1931. [CrossRef]

112. Jing, Y.; Cui, D.; Bao, F.; Hu, Z.; Qin, Z.; Hu, Y. Tryptophan deficiency affects organ growth by retarding cell expansion in Arabidopsis. Plant J. 2009, 57, 511-521. [CrossRef] 
113. Hermand, D. F-box proteins: More than baits for the SCF? Cell Div. 2006, 1, 30. [CrossRef] [PubMed]

114. Feschotte, C. Transposable elements and the evolution of regulatory networks. Nat. Rev. Genet. 2008, 9, $397-405$. [CrossRef] [PubMed]

115. Gogvadze, E.; Buzdin, A. Retroelements and their impact on genome evolution and functioning. Cell Mol. Life Sci. 2009, 66, 3727-3742. [CrossRef] [PubMed]

116. Goodier, J.L.; Kazazian, H.H., Jr. Retrotransposons revisited: The restraint and rehabilitation of parasites. Cell 2008, 135, 23-35. [CrossRef]

117. Casacuberta, E.; Gonzalez, J. The impact of transposable elements in environmental adaptation. Mol. Ecol. 2013, 22, 1503-1517. [CrossRef]

118. Chu, C.G.; Tan, C.T.; Yu, G.T.; Zhong, S.; Xu, S.S.; Yan, L. A novel retrotransposon inserted in the Dominant Vrn-B1 allele confers spring growth habit in tetraploid wheat (Triticum turgidum L.). G3 (Bethesda) 2011, 1, 637-645. [CrossRef]

119. Kanazawa, A.; Liu, B.; Kong, F.; Arase, S.; Abe, J. Adaptive evolution involving gene duplication and insertion of a novel Ty1/copia-like retrotransposon in soybean. J. Mol. Evol. 2009, 69, 164-175. [CrossRef]

120. Lin, R.; Ding, L.; Casola, C.; Ripoll, D.R.; Feschotte, C.; Wang, H. Transposase-derived transcription factors regulate light signaling in Arabidopsis. Science 2007, 318, 1302-1305. [CrossRef]

121. Yan, L.; Fu, D.; Li, C.; Blechl, A.; Tranquilli, G.; Bonafede, M.; Sanchez, A.; Valarik, M.; Yasuda, S.; Dubcovsky, J. The wheat and barley vernalization gene VRN3 is an orthologue of FT. Proc. Natl. Acad. Sci. USA 2006, 103, 19581-19586. [CrossRef]

122. Singh, V.K.; Jain, M. Genome-wide survey and comprehensive expression profiling of Aux/IAA gene family in chickpea and soybean. Front. Plant Sci. 2015, 6, 918. [CrossRef]

123. Baskin, T.I.; Wilson, J.E. Inhibitors of protein kinases and phosphatases alter root morphology and disorganize cortical microtubules. Plant Physiol. 1997, 113, 493-502. [CrossRef] [PubMed]

124. Yang, X.; Li, L. miRDeep-P: A computational tool for analyzing the microRNA transcriptome in plants. Bioinformatics 2011, 27, 2614-2615. [CrossRef] [PubMed]

125. Livak, K.J.; Schmittgen, T.D. Analysis of relative gene expression data using real-time quantitative PCR and the $2^{-\Delta \Delta C}$ T method. Methods 2001, 25, 402-408. [CrossRef] [PubMed]

126. Serivichyaswat, P.T.; Susila, H.; Ahn, J.H. Elongated hypocotyl 5-homolog (HYH) negatively regulates expression of the ambient temperature-responsive microRNA gene MIR169. Front. Plant Sci. 2017, 8, 2087. [CrossRef] [PubMed]

Publisher's Note: MDPI stays neutral with regard to jurisdictional claims in published maps and institutional affiliations.

(C) 2020 by the authors. Licensee MDPI, Basel, Switzerland. This article is an open access article distributed under the terms and conditions of the Creative Commons Attribution (CC BY) license (http://creativecommons.org/licenses/by/4.0/). 